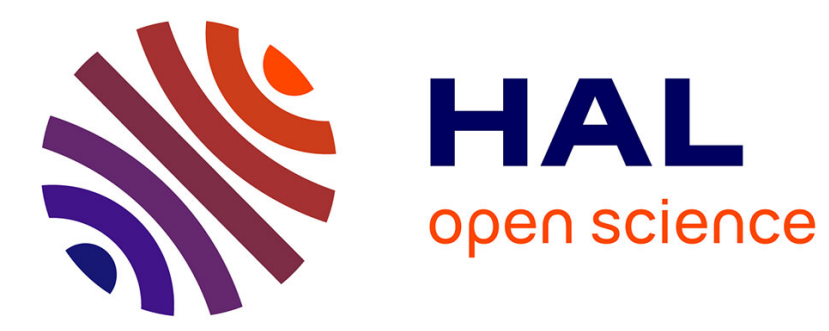

\title{
Occurrence and distribution of glycerol dialkyl glycerol tetraethers in a French peat bog
}

\author{
Arnaud Huguet, Céline Fosse, Fatima Laggoun-Défarge, Marie-Laure
}

Toussaint, Sylvie Derenne

\section{- To cite this version:}

Arnaud Huguet, Céline Fosse, Fatima Laggoun-Défarge, Marie-Laure Toussaint, Sylvie Derenne. Occurrence and distribution of glycerol dialkyl glycerol tetraethers in a French peat bog. Organic Geochemistry, 2010, 41 (6), pp.559-572. 10.1016/j.orggeochem.2010.02.015 . insu-00460433

\section{HAL Id: insu-00460433}

\section{https://hal-insu.archives-ouvertes.fr/insu-00460433}

Submitted on 12 Mar 2010

HAL is a multi-disciplinary open access archive for the deposit and dissemination of scientific research documents, whether they are published or not. The documents may come from teaching and research institutions in France or abroad, or from public or private research centers.
L'archive ouverte pluridisciplinaire HAL, est destinée au dépôt et à la diffusion de documents scientifiques de niveau recherche, publiés ou non, émanant des établissements d'enseignement et de recherche français ou étrangers, des laboratoires publics ou privés. 
Occurrence and distribution of glycerol dialkyl glycerol tetraethers in a French peat bog

Arnaud Huguet ${ }^{\mathrm{a}}$, Céline Fosse ${ }^{\mathrm{b}}$, Fatima Laggoun-Défarge ${ }^{\mathrm{c}}$, Marie-Laure Toussaint ${ }^{\mathrm{d}}$, Sylvie Derenne ${ }^{\mathrm{a} *}$

${ }^{a}$ BioEMCo, CNRS UMR 7618, Université Pierre et Marie Curie, 4 place Jussieu, Paris, F75252 France

${ }^{\mathrm{b}}$ ENSCP, Laboratoire de Spectrométrie de Masse, 11 rue Pierre et Marie Curie, Paris, F75231 France

' Université d'Orléans, Université François Rabelais - Tours, CNRS/INSU, Institut des Sciences de la Terre d'Orléans UMR 6113, 1 A rue de la Férollerie, Orléans, F-45071 France

${ }^{\mathrm{d}}$ Laboratoire Chrono-Environnement, CNRS/INRA UMR 6249, Université de FrancheComté, 4 place Tharradin, Montbéliard, F-25211 France

\section{ABSTRACT}

The present study was aimed at examining the distribution and abundance of glycerol dialkyl glycerol tetraethers (GDGTs) of archaeal and bacterial origin in peat samples from surface and deep (ca. $50 \mathrm{~cm}$ ) horizons of a peat bog in the Jura Mountains (northeastern France). Two principal types of GDGTs are present: extractable GDGTs, recoverable by solvent extraction, and non-extractable GDGTs, linked to the soil matrix. Within the extractable pool, "free" (i.e. core lipids) and "bound" (i.e. intact polar and/or ester-bound lipids) GDGTs can be distinguished. Extractable "free" and "bound" GDGTs were extracted using both accelerated solvent extraction (ASE) and a modified Bligh and Dyer technique. Both methods were shown to allow adequate extraction of "free" archaeal and bacterial GDGTs from soil samples. Both extraction protocols afforded similar relative distributions of archaeal and bacterial GDGTs, although poorer extraction of "bound" GDGTs was observed for ASE relative to Bligh and Dyer. Even though only low amounts of bacterial GDGTs were released after acid hydrolysis of solvent-extracted samples, non-extractable and total extractable GDGTs showed different distribution patterns in some samples. Consequently,

\footnotetext{
* Corresponding author. Tel : + 33-144-273-514 fax : +33-144-275-150.

E-mail address: sylvie.derenne@upmc.fr (S. Derenne).
} 
these two lipid pools potentially reflect different proxy records of mean annual air temperature (MAAT) and $\mathrm{pH}$. Last, the distribution of bacterial GDGTs differed between the different samples. Samples from deep horizons gave lower GDGT-derived MAAT values than those from surficial horizons, in agreement with measured soil temperatures at $7 \mathrm{~cm}$ and $50 \mathrm{~cm}$ depths from April to September. MAAT estimates more closely resemble spring and summer temperatures rather than annual soil temperature. The variability in bacterial GDGT distribution and resulting MAAT estimates probably also reflects the heterogeneity of peat samples and the variation in several environmental factors such as peat moisture level and oxygen availability.

Keywords: Glycerol dialkyl glycerol tetraethers, extractable lipids, non-extractable lipids, bacteria, archaea, peat bogs

\section{Introduction}

Archaea are prokaryotic microorganisms, phylogenetically distinct from Bacteria and Eucarya (Woese et al., 1990). Besides the composition of 16S rRNA genes, Archaea and Bacteria also differ in their membrane lipid composition. Bacteria generally synthesise membrane lipids composed of straight or branched alkyl chains linked by ester bonds to the glycerol backbone. In contrast, archaeal membranes are generally composed of isoprenoid alkyl chains linked by ether bonds to the glycerol backbone, forming glycerol dialkyl diether and glycerol dialkyl glycerol tetraether lipids (GDGTs). Archaeal GDGTs are complex lipids of high molecular weight (>1000 Da; see Appendix for structures) and are ubiquitous compounds in marine and lacustrine water columns (e.g. Karner et al., 2001; Keough et al., 2003), sediments (e.g. Lipp et al., 2008; Teske and Sørensen, 2008), as well as in peat and soil (e.g. Buckley et al., 1998; Leininger et al., 2006; Weijers et al., 2009).

Another group of GDGT lipids, containing branched instead of isoprenoid alkyl chains (cf. Appendix for structures), was discovered in peat bogs by Sinninghe Damsté et al. (2000). 
Based on aspects of their structures and stereochemistry, branched GDGTs were suggested to be produced by unknown bacteria in soils (Weijers et al., 2006a). They were shown to occur ubiquitously in soils (e.g. Weijers et al., 2006b, 2007a; Peterse et al., 2009a), hot springs (Schouten et al., 2007), lake sediments (Blaga et al., 2009; Tierney et al., 2009), as well as in coastal and marine sediments (e.g. Hopmans et al., 2004; Kim et al., 2007), where they derive from fluvially transported terrestrial organic matter (OM). Through the analysis of a large set of soil samples collected from more than 90 different locations worldwide, Weijers et al. (2007a) showed that the relative distribution of branched GDGTs was determined primarily by two environmental parameters: air temperature and soil $\mathrm{pH}$. The degree of methylation, expressed in the methylation index of branched tetraethers (MBT), was shown to depend on mean annual air temperature (MAAT) and to a lesser extent on soil $\mathrm{pH}$, whereas the relative abundance of cyclopentyl rings of branched GDGTs, expressed in the cyclisation ratio of branched tetraethers (CBT), was observed to correlate well with soil $\mathrm{pH}$ (Weijers et al., 2007a). The MBT and CBT indices have recently been shown to be useful tools for the reconstruction of continental temperatures (e.g. Weijers et al., 2007b; Schouten et al., 2008; Rueda et al., 2009).

In living cells, most of the tetraethers are bound to a polar head group (sugar or/and phosphate units; Nishihara and Koga, 1987). Upon cell death or lysis, polar head groups bound to core GDGTs are probably quickly lost, as shown for bacterial ester lipids (e.g. White et al., 1979). Intact polar lipids (glyco- and phospholipids) therefore indicate the presence of living microorganisms, whereas core lipids, which are degraded less easily than intact polar lipids, are considered biomarkers for dead or lysed cells. To date, most studies of GDGTs in soil have focussed on extractable core lipid GDGTs (e.g. Weijers et al., 2007a; Peterse et al., 2009a, b), defined in this paper as extractable "free" GDGTs, and usually recovered using accelerated solvent extraction (ASE). Nevertheless, GDGTs can also occur as extractable 
"bound" lipids in organic extracts, i.e. as intact polar and/or ester-bound lipids. This implies that extractable "free" GDGTs, which have been mainly investigated till now, are not necessarily representative of the total extractable (i.e. "free" + "bound") soil GDGTs, as recently shown for several podzol samples (Huguet et al., 2010). Both the extractable "free" and "bound" lipid pools have therefore to be investigated.

A modified Bligh and Dyer solvent extraction is typically used for the analysis of intact polar lipids (e.g. Pitcher et al., 2009). Nevertheless, this method is relatively time consuming, unlike ASE, which is a rapid and automated extraction technique, employing very small extractant volumes (Bodin et al., 2009). In the frame of the present study, we assess the potential of using ASE instead of the conventional Bligh and Dyer technique for the extraction of both extractable "free" and "bound" GDGTs from soil samples.

In addition to the aforementioned extractable "free" and "bound" pools, lipids in soils can occur as non-extractable lipids, covalently linked to the mineral or organic matrix. Nonextractable lipids can be released from solvent extracted soils through different chemical treatments, such as acid hydrolysis and base hydrolysis, and are often better preserved than extractable lipids (e.g. Albaigès et al., 1984; Kawamura and Ishiwatari, 1984) because of the protection provided by the soil matrix. Non-extractable lipids can therefore provide detailed biogeochemical information concerning the origin and input of lipids in soils or sediments (e.g. Garcette-Lepecq et al., 2004; Disnar et al., 2005; Otto et al., 2006). In addition, the environmental data obtained from the extractable and non-extractable lipid pools may differ. Thus, we recently compared the abundance and distribution of bacterial and archaeal GDGTs in the extractable and non-extractable fractions of two podzols located in temperate and tropical environments (Huguet et al., submitted). We observed that extractable and nonextractable GDGTs could have different distribution patterns and that different MAAT values could be derived from the two lipid fractions,emphasising the interest in investigating both the 
extractable and non-extractable GDGT pools.

In this study, GDGT composition and abundance were therefore examined in the extractable "free", total extractable (i.e. "free" + "bound") and non-extractable lipid pools in order to obtain comprehensive information on bacterial and archaeal GDGTs (Fig .1). To this end, ASE and a modified Bligh and Dyer technique were both applied to the extraction of total extractable GDGTs from soil samples, allowing comparison of the efficiency of the two methods for the extraction of "free" and "bound" GDGTs. Non-extractable GDGTs were then recovered using acid hydrolysis of ASE-extracted soils.

The distribution and abundance of extractable "free", extractable "bound" and nonextractable GDGTs obtained from a French peat bog were compared. To date, few studies have investigated the distribution and abundance of archaeal and bacterial GDGTs in peat bogs (Sinninghe Damsté et al., 2000; Schouten et al., 2000; Weijers et al., 2004, 2006a). Nevertheless, Sphagnum-dominated peat bogs represent one of the most extensive types of northern wetlands in Eurasia and North America (Kotsyurbenko et al., 2004; Dedysh et al., 2006). They are specific soils, characterized by high acidity ( $\mathrm{pH} 3.5$ to 5.0), high organic matter $(\mathrm{OM})$ content, low concentration of nutrient salts and low temperatures (Dedysh et al., 2006). Even though they occupy only ca. 3\% of the terrestrial surface (Kivinen and Pakarinen, 1981), the environmental and ecological significance of peat soils is immense, since northern wetlands contribute up to $50 \%$ to the global production of the greenhouse gas methane (Matthews and Fung, 1987; Harriss et al., 1993) and they represent ca. 30\% of the global reserves of soil organic carbon (Gorham, 1991), as a result of low biodegradation activity in these ecosystems (Comont et al., 2006). In addition to the high organic carbon preservation, ombrotrophic mires are of great interest for climate studies since they are hydrologically independent of groundwater (Laiho, 2006) and consequently their substrate moisture levels are directly related to atmospheric conditions. In the perspective of global 
climatic changes, it is not known how a moderate temperature rise will affect the pool of peat $\mathrm{OM}$ and hence the long term carbon sequestration potential. Peat bogs consist of two distinct layers: an upper aerobic layer in which the water table level fluctuates (acrotelm layer) and a deeper, anoxic part which is continuously water saturated (catotelm layer). The aim of the present work was to study the distribution and abundance of archaeal and bacterial GDGTs in both acrotelm and catotelm parts of a Sphagnum-dominated peatland in Northeastern France.

\section{Materials and methods}

\subsection{Sample collection}

Samples were collected in June 2008 from the Frasne peatland $\left(46^{\circ} 49^{\prime} \mathrm{N}, 6^{\circ} 10^{\prime} \mathrm{E}\right)$, an undisturbed Sphagnum-dominated mire in the Jura Mountains (France), which has been described in detail (Laggoun-Défarge et al., 2008). The site is protected by the EU Habitat Directive of Natura 2000 and has been classified as a Region Natural Reserve for more than 20 yr. Annual precipitation is about $1300-1500 \mathrm{~mm}$ per year, with a mean annual air temperature of $7-8{ }^{\circ} \mathrm{C}$.

Samples were collected from two contrasting sites: (i) a transitional Sphagnum-dominated poor fen site and (ii) an open bog site with mixed vegetation (Sphagnum spp., Eriophorum and other vascular plants, e.g. Andromeda polifolia), where the humidity level is lower than at the first site. The latter site is hereafter called the "dry site" and the former the "wet site". At each site, one sample was collected from the acrotelm layer and another from the catotelm layer. The acrotelm-catotelm boundary was at ca. $25 \mathrm{~cm}$ at both dry and wet sites. Samples from the dry site were collected from between 10 and $12.5 \mathrm{~cm}$ depth (sample FDs) and 42.5 and $47.5 \mathrm{~cm}$ depth (sample FDb). Samples from the wet site were collected between 15 and $17.5 \mathrm{~cm}$ (FWs) and between 42.5 and $47.5 \mathrm{~cm}$ (sample FWb). Samples were stored at $-20{ }^{\circ} \mathrm{C}$. 
They were then freeze-dried, powdered with a mortar and pestle and homogenized before extraction and analysis.

\subsection{Sample preparation for GDGT analysis}

Extractable "free", total extractable (i.e. "free" + "bound") and non-extractable lipid fractions were obtained from ca. 3 to $4 \mathrm{~g}$ aliquots (Fig. 1). All samples were extracted using: (i) ASE and (ii) a modified Bligh and Dyer technique. For ASE, each sample was extracted (3 $\times 5 \mathrm{~min}$ each) with a ca. $50 \mathrm{ml}$ dichloromethane $(\mathrm{DCM}): \mathrm{MeOH}(9: 1, \mathrm{v} / \mathrm{v})$ using an accelerated solvent extractor (ASE 100, Dionex) at $100^{\circ} \mathrm{C}$ and $10 \times 10^{6} \mathrm{~Pa}$.

The Bligh and Dyer extractions $(3 \times)$ were performed according to the protocol of Pitcher et al. (2009). Briefly, a solvent mixture ( $8 \mathrm{ml}$ per $\mathrm{g}$ of peat and extraction step) of $\mathrm{MeOH}$ : DCM: phosphate buffer $(2: 1: 0.8 ; \mathrm{v} / \mathrm{v} / \mathrm{v})$ was added to the sample in a centrifuge tube, and the mixture placed in an ultrasonic bath (10 min). DCM and phosphate buffer were then added to give a new volume ratio $(1: 1: 0.9, \mathrm{v} / \mathrm{v} / \mathrm{v})$. Each extraction was followed by centrifugation $(10$ min, $3500 \mathrm{rpm}$ ) and all extracts were collected in a separation funnel. The DCM layer was separated from the $\mathrm{MeOH} /$ phosphate buffer phase, which was again extracted with DCM (2 $\times)$. The DCM fractions were combined and dried over $\mathrm{Na}_{2} \mathrm{SO}_{4}$.

\subsubsection{Total extractable GDGTs}

For each soil sample, half of the extract obtained using ASE or Bligh and Dyer technique was concentrated under reduced pressure to a residual volume and hydrolysed for $24 \mathrm{~h}$ at 100 ${ }^{\circ} \mathrm{C}$ in $1 \mathrm{M} \mathrm{HCl} / \mathrm{MeOH}$ to release extractable "bound" GDGTs (i.e. intact polar and/or esterbound GDGTs). The mixture was diluted in $\mathrm{MeOH}$ and rotary evaporated under near vacuum $(3 \times)$ to neutralise the hydrolysed aliquot. The hydrolysed extract was separated into three fractions over a $2 \mathrm{~cm}$ diameter alumina column (with a proportion of $10 \mathrm{~g} \mathrm{Al}_{2} \mathrm{O}_{3}$, activated for 
$2 \mathrm{~h}$ at $150{ }^{\circ} \mathrm{C}$ for $0.1 \mathrm{~g}$ lipid extract) using the same volumes (ca. $\left.40 \mathrm{ml}\right)$ of hexane:DCM (9:1, v/v), DCM:MeOH (1:1, v/v) and DCM:MeOH (1:3, v/v) respectively. The medium polarity fraction [DCM:MeOH $(1: 1 \mathrm{v} / \mathrm{v})]$ was reduced using rotary evaporation, dried further under $\mathrm{N}_{2}$, ultrasonically dissolved in hexane:isopropanol $(99: 1, \mathrm{v} / \mathrm{v})$ and centrifuged using an Eppendorf MiniSpin centrifuge (1 min, $7000 \mathrm{rpm})$. The supernatant, containing total extractable GDGTs (i.e extractable "free" + "bound" GDGTs), was collected and analysed using high performance liquid chromatography/atmospheric pressure chemical ionisation mass spectrometry (HPLC/APCI-MS).

\subsubsection{Extractable "free" GDGTs}

The other half of the total extract obtained after ASE or Bligh and Dyer extraction was directly fractionated over an alumina column as described above. Extractable "free" GDGTs were thereby recovered.

\subsubsection{Non-extractable GDGTs}

The peat residues obtained after ASE extraction were subjected to acid hydrolysis. Typically, a dry residue ( $3 \mathrm{~g})$ was refluxed for $24 \mathrm{~h}$ at $100{ }^{\circ} \mathrm{C}$ in aqueous $6 \mathrm{M} \mathrm{HCl}$. After cooling, the suspension was centrifuged for $10 \mathrm{~min}$ at $3500 \mathrm{rpm}$ and the supernatant transferred to a separation funnel. The residue was extracted with water $(3 \times), \mathrm{MeOH} / \mathrm{water}$ $(1: 1 ; 1 \times), \mathrm{MeOH}(2 \times)$ and DCM $(2 \times)$. Each extraction was followed by centrifugation and all extracts were collected in the separation funnel. The DCM layer was separated from the $\mathrm{MeOH} /$ water layer, which was again extracted with DCM $(3 \times)$. The DCM fractions were combined and, after evaporation of the solvent, the extracts were fractionated into apolar, medium polarity and polar fractions as described above. Non-extractable GDGT lipids were thus recovered in the medium polar fraction.

\subsection{HPLC/APCI-MS}


HPLC/APCI-MS analysis was performed with an Agilent 1100 series high performance liquid chromatograph equipped with an automatic injector coupled to a PE Sciex API 3000 mass spectrometer. GDGTs were analysed using a procedure modified from Hopmans et al. (2000) and Weijers et al. (2007a). Separation was achieved with a Prevail Cyano column (2.1 $\mathrm{mm} \times 150 \mathrm{~mm}, 3 \mu \mathrm{m}$; Alltech, Deerifled, IL, USA) thermostatted at $30{ }^{\circ} \mathrm{C}$. Injection volume was $10 \mu$ l. GDGTs were first eluted isocratically with $99 \% \mathrm{~A} / 1 \% \mathrm{~B}$ for $5 \min (\mathrm{A}=$ hexane, $\mathrm{B}$ = isopropanol. The following linear gradient was subsequently used: $99 \% \mathrm{~A} / 1 \% \mathrm{~B}$ to $98 \%$ $\mathrm{A} / 2 \% \mathrm{~B}$ in $45 \mathrm{~min}$, maintained for $5 \mathrm{~min}$, followed by $98 \% \mathrm{~A} / 2 \% \mathrm{~B}$ to $90 \% \mathrm{~A} / 10 \% \mathrm{~B}$ in 1 min, maintained for 10 min and then back to $99 \% \mathrm{~A} / 1 \% \mathrm{~B}$ in $1 \mathrm{~min}$, maintained for $10 \mathrm{~min}$. The flow rate was set at $0.2 \mathrm{ml} / \mathrm{min}$.

Detection was performed using positive-ion APCI. Ion scanning was performed in pseudo-single ion monitoring (SIM) mode, i.e. scanning was from $\mathrm{m} / \mathrm{z} 1290$ to 1310 for the detection of $[\mathrm{M}+\mathrm{H}]^{+}$ions of archaeal GDGTs (I - VI) and from $\mathrm{m} / \mathrm{z} 1044$ to 1054,1030 to 1040 and 1015 to 1025 for the detection of the $[\mathrm{M}+\mathrm{H}]^{+}$ions of bacterial GDGTs VII, VIII and IX, respectively. Quantification was achieved by using an internal standard (see Appendix) synthesised according to Svenson and Thompson (1998). A solution of the internal standard $(0.02 \mathrm{mg} / \mathrm{ml})$ was added to each sample at the end of its preparation for HPLC/MS analysis (i.e. after evaporation of the medium polarity fraction). Typically, $1 \mu \mathrm{g}$ internal standard was added to $1 \mathrm{mg}$ of the medium polarity fraction obtained after separation of the total lipid extract over the alumina column. A correction for the different ionisation efficiency of the internal standard vs. the GDGTs was not applied, implying that semi-quantitative data were obtained. Based on duplicate HPLC/MS analyses, the HPLC/MS analysis error for GDGT quantification with the internal standard was ca. $10 \%$.

The MBT and CBT indices were calculated as follows (Weijers et al., 2007a):

$$
M B T=\frac{[I X a+I X b+I X c]}{[V I I a+V I I b+V I I c]+[V I I I a+V I I I b+V I I I c]+[I X a+I X b+I X c]} \quad \text { Eq. } 1
$$




$$
C B T=-\log \left(\frac{[\text { VIIIb] }]+[I X b]}{[\text { VIIIa }]+[I X a]}\right)
$$

The Roman numerals correspond to the structures in the Appendix. Average duplicate errors for the MBT and CBT indices are 0.005 and 0.02 respectively.

\section{4. $\mathrm{pH}$ and elemental analysis}

The $\mathrm{pH}$ was measured in ultrapure water (Milli-Q, Millipore) with a 1:2.5 peat:water ratio. Total organic carbon (TOC) content was measured at the "Service Central d'Analyse du CNRS”, Vernaison, France.

\section{Results and discussion}

\subsection{Abundance of archaeal and bacterial GDGTs in the three lipid pools}

The abundances of archaeal and bacterial GDGTs were determined for the extractable "free", total extractable and non-extractable lipid fractions of the four peat samples. The results in Figs. 2 and 3 and Table 1 show that archaeal (I-V) and bacterial (VII-IX) GDGTs were present in the three lipid fractions of all samples. Nevertheless, archaeal GDGTs were much less abundant than bacterial GDGTs. In the same way, extractable "free" bacterial GDGTs were previously observed to be more abundant than "free" archaeal GDGTs in two peat bogs (Weijers et al., 2006a).

Comparable amounts of extractable "free" archaeal and bacterial GDGTs were recovered using either the modified Bligh and Dyer technique or ASE (Fig. 2; Table 1). In contrast, the extraction efficiency of ASE for extractable "bound" GDGTs appeared to be sub-optimal as compared with the Bligh and Dyer technique (Fig. 2; Table 1). Indeed, concentrations of extractable "bound" GDGTs were systematically higher (between 32 and 50\% and between 20 and 54\% for bacterial and archaeal GDGTs respectively) in the Bligh and Dyer than in the ASE extract. One hypothesis to explain the difference in extraction efficiency of "bound" 
GDGTs (i.e. intact polar and/or ester-bound GDGTs) between ASE and Bligh and Dyer could be that a proportion of intact polar GDGTs initially present in peat samples are destroyed during ASE because of the high temperature $\left(100^{\circ} \mathrm{C}\right)$ and pressure $\left(10 \times 10^{6} \mathrm{~Pa}\right)$ with this technique. Nevertheless, the loss of head groups from intact polar GDGTs during ASE would lead to the release of additional extractable "free" GDGTs in the ASE extract. Since the concentrations of extractable "free" GDGTs were comparable in the ASE and Bligh and Dyer extracts (Fig. 2), this seems to suggest that thermal decomposition of intact polar GDGTs during ASE was not significant. This is consistent with results obtained by Macnaughton et al. (1997), who compared the efficiency of ASE and Bligh and Dyer technique for the extraction of phospholipid fatty acids from pure culture and environmental samples at different ASE temperatures $\left(80\right.$ and $\left.120{ }^{\circ} \mathrm{C}\right)$. They observed that phospholipid fatty acid yields were not significantly different for soil samples using ASE or Bligh and Dyer, even though extraction recoveries were slightly lower at 120 than at $80{ }^{\circ} \mathrm{C}$.

Another potential explanation for the lower recovery of "bound" GDGTs with ASE could be the lower polarity of the solvent used (DCM/MeOH 9:1, v/v) than for the Bligh and Dyer (MeOH:DCM:phosphate buffer 2:1:0.8; v/v/v at the beginning of the extraction). Nevertheless, the polarity of the extractant seems to have only limited impact on the extraction of "bound" archaeal GDGTs. Indeed, successive extraction of peat sample FDb using ASE $(3 \times)$ and then Bligh and Dyer $(1 \times)$ was performed and did not afford additional GDGTs compared to a simple ASE extraction. The difference in extraction efficiency between ASE and the Bligh and Dyer may be inherent in the techniques and to the workup procedure (column chromatography, centrifugation).

Whatever the extraction method, concentrations of total extractable GDGTs (i.e. extractable "free" and "bound" GDGTs) from archaeal and bacterial origin appear to be much higher in samples collected from the lower part of the Frasne peat bog (samples FDb and 
FWb; Fig. 2). This is consistent with results obtained by Weijers et al. (2006a), who observed that extractable "free" bacterial and archaeal GDGTs were more abundant in the deeper than in the upper part of peat bogs. Since, in contrast to the upper part, the deeper part of peat bogs is continuously water saturated and anoxic, Weijers et al. (2006a) suggested that bacterial GDGTs were produced by anaerobic microorganisms. The present results support this interpretation, all the more so since extractable "bound" bacterial GDGTs, which may be at least partly derived from living branched GDGT-producing bacteria, were observed to be proportionally more abundant in the deep than in the surface horizons of Frasne peat bog (Fig. 2)

The relative abundance of extractable "bound" GDGTs with respect to total extractable GDGTs was determined using both ASE and Bligh and Dyer (Fig. 2). For both types of GDGTs, the proportion of "bound" GDGTs appeared to be at more slightly underestimated when ASE was used instead of Bligh and Dyer (taking into account the HPLC/MS analytical error). Whatever the extraction technique, extractable "bound" archaeal GDGTs represented a significant proportion (between ca. 60 and $75 \%$ according to Bligh and Dyer technique) of total extractable archaeal GDGTs in all peat samples (Fig. 2). It should be noted that, until now, the analysis of archaeal GDGTs in peat bogs has been restricted to the extractable "free" lipid pool, thereby leading to an underestimation of the amount of archaeal GDGTs in peat extracts. In contrast, with archaeal GDGTs, extractable "bound" bacterial GDGTs represented only between 12 and 34\% of total bacterial GDGTs (Bligh and Dyer values).

Some non-extractable GDGTs were released via acid hydrolysis of ASE-extracted samples (Fig. 3), although in low amounts. Non-extractable GDGTs represented between 1 and $12 \%$ of total (i.e. non-extractable and total extractable lipids) bacterial GDGTs and between 0.2 and $4 \%$ of total archaeal GDGTs. Recently, we compared (Huguet et al., submitted) the abundance and distribution of total extractable and non-extractable GDGTs of 
bacterial and archaeal origin along the whole profile of a temperate podzol (including the litter layer), situated $40 \mathrm{~km}$ north of Paris (France). This led us to propose that non-extractable GDGTs would be mainly associated with the inorganic soil matrix. The low abundance of non-extractable GDGTs in the organic-rich peat samples from Frasne tends to support this hypothesis. In order to ensure that the low amounts of non-extractable GDGTs do not result from incomplete extraction of some tetraethers, one of the peat samples (FDb) was extracted using ASE as described above (Section 2.2) and was then further extracted using the modified Bligh and Dyer protocol. No GDGTs could be detected in the Bligh and Dyer extract, confirming that the lipids recovered by acid hydrolysis of the ASE-extracted peat residues were indeed non-extractable using either ASE or the Bligh and Dyer technique. Acid hydrolysis of peat residues likely allows the release of GDGTs bound to, or trapped in, the macromolecular organic matrix.

The relative abundance of bacterial and archaeal tetraethers in the different peat samples was compared by calculating the ratio of total bacterial to total archaeal GDGTs (Table 1). Comparable values of this ratio were obtained for ASE and Bligh and Dyer extractions in both extractable "free" and total extractable lipid fractions, even though a slightly greater variability was observed for sample FDb. The relative amount of bacterial to archaeal GDGTs appeared to be systematically higher in the extractable "free" than in the total extractable lipid fraction (Table 1), as also observed for the previously studied podzol samples (Huguet et al., 2010). As previously indicated, this could be explained by several phenomena, notably the preferential transfer of extractable "free" archaeal GDGTs to the non-extractable lipid pool (e.g. via incorporation of GDGTs into macromolecules in soil). Nevertheless, the latter mechanism would result in a lower relative abundance of bacterial vs. archaeal tetraethers in the non-extractable fraction, whereas the ratio of total bacterial over total archaeal GDGTs was higher in the non-extractable lipid fraction than in the total extractable one for all peat 
samples (Table 1). Instead, the higher amount of bacterial than archaeal GDGTs in the extractable "free" than in the total extractable lipid fraction could potentially be explained by the preferential degradation of extractable "free" archaeal compared to extractable "free" bacterial GDGTs in the Frasne peat bog. This is partly supported by a study of Huguet et al. (2008), who compared the degree of preservation of a marine archaeal GDGT (crenarchaeol) with the one of soil-derived bacterial GDGTs in oxidized marine sediments. These authors observed that, despite the very similar structures of archaeal and bacterial GDGTs, soilderived bacterial GDGTs were degraded two times slower than marine crenarchaeol (GDGT VI). Similarly, it can be anticipated that extractable "free" archaeal GDGTs are more easily degraded than extractable "free" bacterial GDGTs in peat. Nevertheless, our results are unlikely to be totally explained by differences in degradation rates of archaeal and bacterial GDGTs. In fact, molecules with branched alkyl chains have been observed to degrade faster than those with isoprenoid chains (Peters et al., 2005). Furthermore, both archaeal and bacterial "free" GDGTs might be able to survive in marine sediments over several thousands and even millions of years (e.g. Kuypers, 2001; Weijers et al., 2007b) and seem therefore to be relatively resistant to degradation. This is certainly also the case in peat bogs, where decomposition of $\mathrm{OM}$ is slow, notably due to oxygen limitation resulting from flooding, which inhibits microbial activity and enzymatic activity (Laggoun-Défarge et al., 2008). The hypothesis of a slow degradation for GDGTs in peat is consistent with the increasing concentration of both archaeal and bacterial "free" GDGTs with depth observed in this study as well as in some other peat sites (e.g. Weijers et al., 2006a). Archaeal and bacterial GDGTs are likely to be well preserved in peat, implying that the degradation of extractable "free" GDGTs is unlikely to be responsible for such significant differences in the relative abundances of bacterial vs. archaeal GDGTs in the extractable "free" and total extractable lipid pools. 
Alternatively, such differences may be caused by the higher regeneration rate of branched GDGT-producing bacteria than of archaea. Upon cell death, the covalently-bound polar head groups of bacterial ester lipids are typically quickly lost (White et al., 1979). Similarly, it is likely that intact polar GDGTs, considered as biomarkers of living cells, easily lose their polar head groups, resulting in the accumulation of relatively recalcitrant extractable "free" GDGTs in soil. The hypothesis of a higher regeneration rate for branched GDGT-producing bacteria than for archaea implies that more bacterial than archaeal GDGTs are produced over time and therefore that extractable "free" bacterial GDGTs accumulate faster than extractable "free" archaeal GDGTs in peat. This would result in a higher relative abundance of bacterial vs. archaeal GDGTs in the extractable "free" than in the total extractable pool, as observed in this study (Table 1).

In order to explain the differences in bacterial vs. archaeal abundance in the extractable "free", total extractable and non-extractable lipid fractions (Table 1), it might also be assumed that bacterial and archaeal GDGTs contain different types of polar head groups. Polar head groups of archaeal GDGTs were shown to be either purely hexose- and phosphate-based or a mixture of both (e.g. Sturt et al., 2004; Rossel et al., 2008), whereas those of bacterial GDGTs are unknown. The stability of the functional head groups of archaeal and bacterial GDGTs could be different. Phospholipids were notably observed to degrade faster than glycolipids (Harvey et al., 1986). Intact polar archaeal GDGTs might be more resistant to degradation than bacterial ones, resulting in a lower relative abundance of bacterial vs. archaeal GDGTs in the total extractable (containing extractable "free" and "bound" GDGTs) than in the extractable "free" fraction.

The relative amount of bacterial to archaeal GDGTs was observed to be systematically higher in the non-extractable than in the total extractable lipid fraction (Table 1). This could be explained by the preferential incorporation of bacterial GDGTs in the peat macromolecular 
matrix, which might result from the different types of head groups synthesised by bacterial and archaeal GDGTs. Alternatively or complementarily, if the polar head groups of archaeal GDGTs are more stable than those of bacterial GDGTs, extractable "bound" archaeal GDGTs could tend to become sooner and more strongly bound to the peat organic matrix than bacterial GDGTs. Once bound to the peat macromolecular matrix, archaeal GDGTs could be more difficult to retrieve than bacterial ones, leading to a preferential release of nonextractable bacterial GDGTs.

\subsection{Distribution of archaeal and bacterial GDGTs in the three lipid pools}

The distribution and abundance of individual archaeal and bacterial GDGTs were determined in the extractable "free", total extractable and non-extractable lipid fractions of each sample (Table 1). The relative distributions of archaeal and bacterial GDGTs were rather similar for ASE and Bligh and Dyer extractions in both extractable "free" and total extractable lipid fractions, except for sample FDs, where GDGT I represented a higher proportion of total archaeal GDGTs in the Bligh and Dyer extract than in the ASE extract (Table 1). This shows that the extractable "bound" GDGTs obtained through ASE chiefly correspond to those extracted with the Bligh and Dyer technique.

GDGT I was predominant among the archaeal tetraethers and represented $>75 \%$ of total archaeal GDGTs, except for sample FDs, where it represented ca. 55-60\% of the total archaeal GDGTs in the extractable "free" and total extractable fractions according to the ASE technique. GDGT VI (crenarchaeol), which contains a cyclohexane moiety in addition to four cyclopentanes, and its regioisomer (GDGT VI') were virtually absent from all the samples. Crenarchaeol is a specific membrane lipid of the non-thermophilic group I Crenarchaeota, which is always present in marine and lacustrine environments (Sinninghe Damsté et al., 2002; Powers, 2004) and which has also been detected in soils (Weijers et al., 2006b) and 
peat bogs (Weijers et al., 2004). Since it was not detected in the Frasne peat bog, it might be supposed that Crenarchaeota do not represent a major source for GDGTs of archaeal origin in this peat. It must be noted that no crenarchaeol was detected in two peats (Carbury and Bargerveen) by Schouten et al. (2000). In contrast, Weijers et al. (2004) found some in the acrotelm of the Saxnäs Mosse peat but not in its catotelm. According to previous results, archaeal GDGTs could be mainly produced by another group of Archaea, namely methanogenic Euryarchaeota. Indeed, Utsumi et al. (2004) studied archaeal population structures in peat samples from climatically and geographically distinct wetlands and showed that peat-derived $16 \mathrm{~S}$ rDNA sequences were mostly related to Euryarchaeota. In the same way, Kotsyurbenko et al. (2004) showed that methanogens (Euryarchaeota) represented up to $36 \%$ of the total microbial community in samples from a west Siberian peat bog. In addition, methanogenic Euryarchaeota can contain archaeal GDGT I in high amounts (Koga et al., 1993), consistent with the present results showing the predominance of GDGT I among archaeal tetraethers in all the peat samples. This is supported by a study of Pancost et al. (2000), who notably determined the archaeal GDGT distribution of two subboreal peat deposits. These authors observed that acyclic GDGT I was much more abundant than cyclic GDGTs II and III in the different peat bog samples and suggested that GDGT I was likely derived from methanogenic Archaea. The dominant methanogenic origin of archaeal GDGT I was confirmed by a recent study of Weijers et al. (2009), who compared the abundance of this GDGT with quantitative 16S rRNA data of methanogens in the profile of a Swedish peat bog. Methanogenic Euryarchaeota and GDGT I were both shown to be present at high concentration and to be much more abundant in the anoxic than in the oxic part of this peat profile (Weijers et al., 2009).

No significant differences in archaeal GDGT distribution were observed between the extractable "free" and total extractable pools (Table 1). Concentrations of GDGTs II-V were 
too low in the non-extractable pool to achieve a proper determination of archaeal GDGT distribution in this fraction.

Bacterial GDGTs VIIIa and IXa were largely predominant among bacterial tetraethers in the three lipid fractions of all the samples and represented between 82 and $94 \%$ of the total bacterial GDGTs (Table 1). GDGT VIIa, containing one extra methyl with respect to GDGT VIIIa and two extra methyls with respect to GDGT IXa, was present in lower abundance than the two predominant bacterial GDGTs. Bacterial GDGTs containing one or two cyclopentyl moieties (VIIb-IXb and VIIc-IXc) were much less abundant than GDGTs without cyclopentyl moieties (VIIa-IXa), as commonly observed (Weijers et al., 2007a). GDGT VIIc was not detected in any of the samples.

Whatever the extraction method, no significant difference could be noted in the bacterial GDGT distribution between the extractable "free" and total extractable lipid fractions of the samples (Table 1), as confirmed through analysis of the MBT and CBT values (Fig. 4; Table 2). It should also be noted that similar MBT and CBT values were derived from the Bligh and Dyer and ASE extracts, even though a slightly greater variability was observed for CBT (Fig. 4b) than for MBT (Fig. 4a). This suggests that both extraction techniques can be used for the determination of the MBT and CBT proxies.

Comparison between the distributions of bacterial GDGTs in the total extractable and non-extractable fractions revealed some small qualitative differences. For example, the MBT index was higher for the total extractable fraction than for the non-extractable one of samples FWs and FDs (Fig. 4a; Table 2). The opposite was observed for sample FDb. In addition, the CBT ratio was observed to be much higher in the non-extractable than in the total extractable lipid pool of sample FDs (Fig. 4b; Table 2). The differences in CBT values between the total extractable fraction and non-extractable fraction observed in this study have nevertheless to be interpreted with care, since cyclopentane-containing bacterial GDGTs were present in trace 
amounts and/or were even not detected in the non-extractable lipid pool of some samples (Table 1). All these results show that non-extractable GDGTs can present a distribution pattern different from that of total extractable GDGTs, as observed for podzolic soil (Huguet et al., submitted). In some cases, the association of bacterial GDGTs with the peat organic matrix could therefore lead to modifications of the relative abundance and distribution of extractable GDGTs.

Some differences in bacterial GDGT distribution were observed between the different samples (Table 1). These were reflected in the MBT index (Fig. 4a; Table 2) since, whatever the lipid fraction, MBT was observed to be lower for the wet site (samples FW) than for the dry one (samples FD; Fig. 4a). This suggests that peat moisture level has an influence on membrane lipid distribution of branched GDGT-producing bacteria. This hypothesis is consistent with the fact that MBT values (Fig. 4a; Table 2) are on average higher for samples collected from the upper part (FWs/FDs) than for samples collected from the deeper part of the two sites $(\mathrm{FWb} / \mathrm{FDb})$. Indeed, peat moisture level is higher in the continuously water saturated, deeper part of peat bogs than in the upper part, where the water table moves, particularly at FDs for the Frasne peat bog. A larger set of peat samples has to be analyzed to confirm that the variations in MBT might be partly correlated with those in peat moisture level.

Recently, Peterse et al. (2009c) analysed 59 north American surface soils from different climate zones for bacterial GDGTs and showed that the MBT index was well related $\left(\mathrm{R}^{2} 0.75\right)$ to mean annual precipitation (MAP) for MAP $<2000 \mathrm{~mm}$. MBT was indeed observed to increase with increasing MAP for MAP $<2000 \mathrm{~mm}$, whereas a decrease in MBT was noticed for the few MAP values higher than $2000 \mathrm{~mm}$. Precipitation has a first-order impact on soil moisture (Koster et al., 2004), implying that soil moisture might have an influence on bacterial GDGT distribution, in particular on the MBT index. The results obtained by Peterse 
et al. (2009c) might suggest that the MBT decreases when precipitation level and therefore soil moisture is high, even though this has to be confirmed by analysis of a larger set of soil samples. This hypothesis seems consistent with the observations in this paper for peat samples, i.e. a decrease in MBT with increasing peat moisture level (Table 2).

Changes in GDGT distribution between the different peat samples were also reflected in the CBT index, which increased from the dry site $(1.14-1.47)$ to the wet site $(1.49-1.73)$ and to a lesser extent from surface to depth (Fig. 4b; Table 2). The variability in the MBT and CBT indices cannot be explained solely by variation in $\mathrm{pH}(3.5-3.7)$, which is limited among the different samples and nil for a given depth. Variations in other peat parameters and environmental factors such as peat moisture level (see above discussion) and oxygen content and availability may play a role in the distribution pattern of bacterial GDGTs. Indeed, peat, which is composed of $93-98 \%$ of partially decomposed plant OM (Clymo, 1983), constantly experiences seasonal and spatial deviations in oxygen content (Yavitt et al., 1987; Charman, 2002). Such deviations are also observed in Frasne peat bog, as shown by the systematically higher oxygen indices obtained from Rock-Eval pyrolysis for samples FWs collected at the surface of the wet site (250-300 $\mathrm{mg} \mathrm{O}_{2} / \mathrm{g}$ TOC) than for samples FDs collected at the surface of the dry site (150-200 $\mathrm{mg} \mathrm{O}_{2} / \mathrm{g}$ TOC; Delarue et al., submitted). These spatial variations in oxygen content impact on heterotrophic microbial activity in peat bogs (Wright and Reddy, 2001) and C mineralization rate (Bergman et al., 1999), which were reported to be substantially higher under aerobic conditions. In the same way, oxygen content variations may have an influence on the activity of anaerobic bacteria producing branched GDGTs, which were detected in both anaerobic and aerobic zones of peat bogs. These microorganisms are more abundant in the deeper than in the upper part of peat bogs, where they probably thrive in anaerobic microsites, as suggested by Weijers et al. (2006a). In addition, oxygen content might also have an impact on bacterial GDGT distribution. Altering the oxygen 
content of microorganism growth environment was shown to affect the cellular lipid composition of the bacteria Escherichia coli K-12 (Naccarato et al., 1974) and of the fungus Mucor rouxii (Safe and Ducan, 1974). Cells of Mucor rouxii were cultivated under aerobic and anaerobic conditions, and both quantitative and qualitative differences in the lipid composition of the two types of cells were observed, anaerobic cells containing relatively high levels of short chained fatty acids and very low concentrations of unsaturated acids compared to the aerobic growth conditions (Safe and Duncan, 1974). Similarly, membrane lipid composition of branched GDGT-producing bacteria might be affected by variations in oxygen content, notably in peat bogs.

More generally, the occurrence of lateral and vertical changes in bacterial GDGT abundance and distribution (Fig. 4; Table 2) may be due to the heterogeneity of peat soils and to the subsequent variations in peat properties with depth and along peat sequences (Delarue et al., submitted). In addition, metabolic activity of branched GDGT-producing bacteria might vary over the year and might be lower during periods of dryness or freezing (Weijers et al., 2006b)

\subsection{Reconstruction of air temperature and peat $\mathrm{pH}$}

Peat $\mathrm{pH}$ and mean annual air temperature (MAAT) were estimated from MBT and CBT indices using the following equations given by Weijers et al. (2007a):

$\mathrm{CBT}=3.33-(0.38 \times \mathrm{pH})$

Eq. 3

$\mathrm{MBT}=0.122+(0.187 \times \mathrm{CBT})+(0.020 \times \mathrm{MAAT})$

Eq. 4

The changes in MBT and CBT indices observed along the two peat profiles and between the wet and dry sites were reflected in the variability in MBT/CBT-derived MAAT and CBTderived $\mathrm{pH}$ values (Table 2). The $\mathrm{pH}$ estimates derived from extractable "free" GDGTs in the dry site were 5.2-5.7, whereas those derived from extractable "free" GDGTs at the wet site 
were 4.3-4.8 (Table 2). Taken together, these results show that CBT-pH values derived from extractable "free" GDGTs were higher than actual pH measurements $(3.5-3.7)$.

Comparable $\mathrm{pH}$ estimates were obtained from the ASE and Bligh and Dyer extracts for both extractable "free" and total extractable fractions, despite a slightly greater variability between the two methods for samples from the wet site (Table 2). In addition, the comparison of $\mathrm{pH}$ values derived from extractable "free", total extractable and non-extractable GDGT fractions showed that $\mathrm{pH}$ estimates inferred from the three lipid pools were comparable, except for sample FDs. For this sample, a lower $\mathrm{pH}$ value was derived from non-extractable GDGTs than from extractable "free" and total extractable ones (Table 2). An explanation for the higher $\mathrm{pH}$ estimates in comparison with actual $\mathrm{pH}$ values could be that the correlation between $\mathrm{CBT}$ and soil $\mathrm{pH}$ was obtained from the analysis of 130 soils collected worldwide (Weijers et al., 2007a). Nevertheless, peat soils were not included in the correlation. Calibrations accounting for the specificity of peat environments, where $\mathrm{OM}$ is slowly degraded, could improve the accuracy of peat $\mathrm{pH}$ reconstruction. Furthermore, even though a strong correlation $\left(\mathrm{R}^{2}\right.$ 0.70; Weijers et al., 2007a) was obtained between CBT and pH (Eq. 3), some scatter remains, which may partly explain the uncertainty in the $\mathrm{pH}$ reconstructed values. This uncertainty could also be due to the relatively low abundance of GDGTs VIIIb and IXb, used in the calculation of the CBT index, in peat samples (Table 1).

MAAT was determined from MBT and CBT using Eq. 4. Whatever the lipid fraction, comparable MAAT estimates were obtained using either ASE or Bligh and Dyer extraction (Table 2), even though a slight variability was observed between the two techniques for some of the samples, mainly due to the uncertainty in the CBT values. This suggests that both extraction methods can be used for the reconstruction of MAAT via the MBT/CBT indices.

MAAT values derived from extractable "free" and total extractable GDGTs were relatively similar (Table 2), except for sample FWs. These results seem to suggest that 
comparable data concerning past air temperature could be obtained from extractable "free" GDGTs and total extractable (i.e. "free" + "bound") GDGTs in peat soils, as observed earlier from analysis of GDGTs in extractable "free" and total extractable fractions of several podzol samples (Huguet et al., 2010). If we assume that extractable "free" and extractable "bound" GDGTs are derived respectively from dead and living biomass, this would imply that MAAT estimates obtained from GDGTs of dead and living branched GDGT-producing bacteria do not significantly differ. This has to be confirmed by analysis of a larger set of peat samples.

In contrast, lower MAAT estimates were derived from non-extractable than from extractable "free" and total extractable GDGTs for surficial samples FWs and FDs. This shows that, in some cases, extractable and non-extractable GDGTs can provide different MAAT values, as observed for podzols (Huguet et al., submitted). Non-extractable GDGTs are bound to or trapped in the peat organic matrix. They are likely to be well preserved in peat and may therefore be less easily degraded than extractable GDGTs. It might be supposed that the relative distribution and abundance of non-extractable GDGTs do not vary significantly with time, whereas the opposite might occur for extractable GDGTs. Environmental data, in particular MAAT estimates, obtained from non-extractable GDGTs might therefore differ and also be more reliable than those derived from extractable GDGTs, as shown for podzol soils (Huguet et al., submitted). This hypothesis needs to be tested with more peat samples.

The relatively low concentration of GDGTs VIIIb and IXb in peat samples (Table 1) could bias the calculation of the CBT index. GDGT VIIIb was not even detected in the nonextractable lipid fraction of sample FDb, preventing determination of the CBT. MAAT was therefore also estimated using the following equation (Weijers et al., 2007a):

$\mathrm{MBT}=0.867-(0.096 \times \mathrm{pH})+(0.021 \times \mathrm{MAAT})$ Eq. 5

Similar trends were obtained using Eq. 5 instead of Eq. 4 (Table 2). Nevertheless, whatever the lipid fraction, MAAT estimates derived from peat $\mathrm{pH}$ and MBT index (Eq. 5) were 
systematically much lower than those calculated from MBT and CBT indices (Eq. 4), as observed from analysis of podzol samples from temperate and tropical environments (Huguet et al., 2010; submitted). As previously suggested (Huguet et al., submitted), this discrepancy could be explained (i) by the greater correlation between MBT, MAAT and soil $\mathrm{pH}\left(\mathrm{R}^{2} 0.82\right.$; Eq. 5) than between MBT, CBT and MAAT (R ${ }^{2}$ 0.77; Eq. 4) (Weijers et al., 2007a) and (ii) by the relatively low abundance of cyclopentyl-containing GDGTs VIIIb and IXb in peat samples, which could increase the analytical uncertainty in the CBT index and in the determination of MAAT using Eq. 4. Indeed, whatever the lipid fraction, a lower variability in MAAT estimates was observed when air temperature was calculated using Eq. 5 (Table 2). For example, MAAT values obtained from total extractable GDGT distribution in the four ASE extracts ranged between -4.7 and $3.2^{\circ} \mathrm{C}$ according to Eq. 5 , and between 0.6 and $12.1^{\circ} \mathrm{C}$ according to Eq. 4.

Whatever the lipid fraction, MAAT estimates calculated using Eq. 4 and Eq. 5 (Table 2) were respectively slightly lower (except for sample FDs) and much lower than instrumentally recorded MAAT in the Frasne area (average air temperature $6.8{ }^{\circ} \mathrm{C}$; Table 3). The reconstruction of MAAT using $\mathrm{MBT}$ and $\mathrm{CBT}$ indices is based on the fact that $\mathrm{CBT}$ is mainly determined by soil $\mathrm{pH}$ and the MBT is mainly governed by air temperature and soil $\mathrm{pH}$ (Weijers et al., 2007a). Nevertheless, some scatter remains in the CBT-pH (Eq. 3) and MBTpH-MAAT (Eq. 4) relationships (Weijers et al., 2007a), because other environmental factors than temperature and $\mathrm{pH}$, such as soil moisture or oxygen content, may also be involved in determining the distribution of bacterial GDGTs in soil (Peterse et al. 2009a). The remaining scatter might explain part of the uncertainty in the reconstructed MAAT values for Frasne peat bog. In the same way as for $\mathrm{pH}$ reconstruction (see discussion above), the accuracy of MAAT reconstruction could be improved by using a local calibration taking into account the 
heterogeneity of peat soils rather than a global soil correlation, as also suggested by Sinninghe Damsté et al. (2008) and Peterse et al. (2009a).

Another explanation to the uncertainty in MAAT-reconstructed values could be that Weijers et al. (2007a) used MAAT and not soil temperature in their global soil calibration set. Nevertheless, the distribution of bacterial GDGTs is likely to be more strongly correlated with soil temperature than with air temperature, since growth of branched GDGT-producing bacteria occurs in soil. In topsoil horizons, soil temperatures are largely controlled by air temperature and MAAT can therefore be assumed to be a good approximation for annual soil temperature, as suggested by Weijers et al. (2007a). However, this assumption is not necessarily valid all along the year, in particular for soils which are snow-covered in winter. For example, detail measurements of air and soil temperatures near Obergiirgl, Austria (2072 m) showed that there was a correspondence between average values of soil and air temperatures when the soil was not frozen (Aulitsky, 1962). In contrast, soil temperatures were observed to be lower than air ones in the transition seasons, as a result of radiative cooling of the surface in autumn and of lag effects of the snow cover in spring. Similarly, air and soil temperature at $7 \mathrm{~cm}$ depth were measured during the 2009 year at the wet and dry sites of Frasne peat bog (Table 3) and were shown to be roughly similar for a large part of the year (from April to August as well as in October and November), whereas, when soil was frozen (December to February), soil temperature at $7 \mathrm{~cm}$ was observed to be higher than air temperature at both sites (Table 3). March and September were two transition months, during which soil surface temperature was respectively lower and higher than air temperature (Table 3). More generally, marked differences can be observed between air and soil temperatures in Frasne despite comparable average annual soil surface and air temperatures (Table 3). Indeed, minimal and maximal air temperatures measured over the year 2009 were respectively much lower and much higher than minimal and maximal soil surface temperatures (Table 3). The 
differences between air and soil temperatures could partly explain the lower values of MAAT estimates derived from bacterial GDGTs (Table 2) vs. actual MAAT values in the Frasne peat bog. GDGT-derived MAAT values could be in closer agreement with peat soil temperature than with air temperature.

This also holds for deep samples and may account for the lower MAAT values obtained with respect to surficial horizons (Table 2). Seasonal changes in deep soil temperature can be lower than those in surface soil temperature, and can lag significantly behind seasonal changes in overlying air temperature because of the much higher heat capacity of soil relative to air and the thermal insulation provided by vegetation and surface soil layers. Temperature was indeed observed to vary to a lesser extent in the deep than in the surface horizons of the Frasne peat bog over the year 2009 (Table 3). In addition, lower soil temperatures were measured in the deep horizons of the Frasne peat bog than in the surface ones during the spring and summer seasons (from April to September; Table 3), whereas an opposite trend was observed during the coldest months of the year. Samples collected from deep peat horizons gave GDGT-derived MAAT values lower than those collected from surficial horizons (Table 2), implying that MAAT estimates derived from bacterial GDGTs could be in closer agreement with spring and summer soil temperature rather than with annual soil or air temperature. Similarly, Rueda et al. (2009) have recently compared instrumental and GDGTbased estimates of sea surface and air temperatures in a marine sediment core from the Skagerrak, off Southern Norway, and have observed that the average air temperature values estimated from MBT and CBT for the last $200 \mathrm{yr}$ were in closer agreement with recorded summer air temperatures than with annual air temperatures. According to Rueda et al. (2009), one possible explanation could be that branched GDGT-synthesising bacteria are more active during summer than the rest of the year, since Scandinavian soils are snow-covered for several months. Such an explanation might also hold for the peat bog investigated in the 
present study, where soil temperature was observed to vary over a large range, whatever the depth (Table 3). These large variations in temperature could influence the activity and distribution pattern of branched GDGT-producing bacteria in the Frasne peat bog. The latter might be more active during the spring and summer months and their membrane lipid distribution might therefore reflect seasonal rather than annual soil temperature.

\section{Conclusions}

The distribution and abundance of bacterial and archaeal GDGTs were compared in the extractable "free", total extractable (i.e. extractable "free" and extractable "bound" lipids) and non-extractable lipid fractions of peat samples collected from Frasne peat bog in northeastern of France. Extractable "free" and extractable "bound" GDGTs were extracted using both ASE and a modified Bligh and Dyer technique. The two methods allowed "free" archaeal and bacterial GDGTs to be extracted adequately. Even though a lower efficiency was observed for the extraction of "bound" GDGTs using ASE instead of Bligh and Dyer, the proportion of "bound" GDGTs with respect to total extractable GDGTs was the same regardless of the extraction method. Moreover, comparable relative distributions of archaeal and bacterial GDGTs were obtained using the two techniques, implying that similar environmental information (i.e. past air temperature and soil $\mathrm{pH}$ ) can be derived from bacterial GDGT distribution using either ASE or Bligh and Dyer extraction. Taken together, the results suggest that, besides being rapid and automated, ASE is a viable method for the extraction of total extractable GDGTs from peat samples.

Extractable "bound "GDGTs were shown to represent a significant proportion of total extractable archaeal GDGTs in all samples, whereas bacterial GDGTs were present mainly as extractable "free" GDGTs in the extracts. In addition, distributions of archaeal and bacterial GDGTs were observed to be relatively similar in the extractable "free" and total extractable 
fractions and comparable $\mathrm{pH}$ and mean air temperature values were derived from extractable "free" and total extractable lipid pools. As a result, extractable "free" and total extractable GDGTs might provide comparable environmental information. This has to be confirmed by analysis of a larger set of peat samples.

Only low amounts of non-extractable GDGTs were released after acid hydrolysis of extracted samples. Nevertheless, we observed that total extractable and non-extractable GDGTs could show different distribution patterns, so different MAAT and $\mathrm{pH}$ values can be derived from these two lipid pools. Our results suggest that data derived from extractable GDGTs must be analysed with care and should be compared with those derived from nonextractable GDGTs.

The relative abundance of archaeal and bacterial GDGTs in the different peat samples was compared. The relative amount of bacterial to archaeal GDGTs was systematically higher in the extractable "free" than in the total extractable fraction for all samples. A possible explanation is that branched GDGT-producing bacteria have a higher regeneration rate than archaea and that more bacterial than archaeal GDGTs are produced over time, resulting in a faster accumulation of "free" bacterial GDGTs than archaeal ones in peat. In addition, the ratio of total bacterial over total archaeal GDGTs was systematically higher in the nonextractable than in the total extractable fraction for all samples, likely indicating the preferential incorporation of bacterial GDGTs in the peat macromolecular matrix.

No crenarchaeol was detected, suggesting that archaeal GDGTs are likely mainly produced by methanogenic Euryarchaeota. We also observed that the distribution of bacterial GDGTs differed between samples, notably between surficial and deep peat horizons. These differences were reflected in the variability in the GDGT-derived MAAT estimates, since samples collected from deep peat horizons gave lower MAAT values than those collected from surficial horizons, in agreement with measured soil temperatures at $7 \mathrm{~cm}$ and $50 \mathrm{~cm}$ 
depths from April to September. This implies that branched GDGT-producing bacteria might be more active during the spring and summer months in the Frasne peat bog and that their membrane lipid distribution might reflect seasonal rather than annual soil temperature. The variability in bacterial GDGT distribution and thus of temperature estimates should also reflect variations in several environmental factors such as peat moisture level and oxygen availability. In addition, GDGT-derived MAAT values were generally lower than instrumentally recorded MAAT values, partly because GDGT- derived values could reflect soil temperature rather than air temperature. All the results suggest that caution must be exercised when applying and interpreting data derived from bacterial GDGTs in complex ecosystems such as peat bogs. Local calibrations taking into account the specificity of peat soils may improve the accuracy of MAAT and peat $\mathrm{pH}$ reconstruction.

\section{Acknowledgments}

This paper is a contribution of the PEATWARM project (Effect of moderate warming on the functioning of the Sphagnum peatlands and their function as carbon sink) financially supported by the French National Agency (ANR-07-VUL-010). We gratefully acknowledge the Regional Council of Ile de France for funding. X. Liu and two anonymous reviewers are thanked for constructive comments.

Associate Editor - K.-U. Hinrichs

\section{References}

Albaigès, J., Algaba, J. Grimalt, J, 1984. Extractable and bound neutral lipids in some lacustrine sediments. In: Schenck, P.A., de Leeuw, J.W., Lijmbach, G.W.M. (Eds.), Advances in Organic Geochemistry 1983. Pergamon Press, Oxford, pp. 223-236.

Aulitsky, H., 1962. Soil temperature conditions on a central Alpine slope on both sides of the timberline. Part 3: Soil temperature in relationship to other climatic factors (soil temperature, surface temperature, and climatic factors in mountain and plains regions). 
Archiv für Meteorologie Geophysik und Bioklimatologie Serie B-Klimatologie Umweltmeteorologie Strahlungsfroschung (Vienna) 2, 363-376.

Bergman, I., Lundberg, P., Nilsson, M., 1999. Microbial carbon mineralization in an acid surface peat: effects of environmental factors in laboratory incubations. Soil Biology and Biochemistry 31, 1867-1877.

Blaga, C.I., Reichart, G.-J., Heiri, O., Sinninghe Damsté, J.S., 2009. Tetraether membrane lipid distributions in water-column particulate matter and sediments: a study of 47 European lakes along a north-south transect. Journal of Paleolimnology 41, 523-540.

Bodin, N., Budzinski, H., Le Ménach, K., Tapie, N., 2009. ASE extraction method for simultaneous carbon and nitrogen stable isotope analysis in soft tissues of aquatic organisms. Analytica Chimica Acta 643, 54-60.

Buckley, D.H., Graber, J.R., Schmidt, T.M., 1998. Phylogenetic analysis of nonthermophilic members of the kingdom Crenarchaeota and their diversity and abundance in soils. Applied and Environmental Microbiology 64, 4333-4339.

Charman, D., 2002. Peatlands and Environmental Change. John Wiley and Sons, West Sussex, England, 312 pp.

Clymo, R.S., 1983. Peat. In: Gore, A.J.P. (Ed.), Ecosystems of the World 4A. Elsevier Scientific, Amsterdam, pp. 159-224.

Comont L., Laggoun-Défarge F., Disnar, J.R., 2006. Evolution of organic matter indicators in response to major environmental changes: the case of a formerly cut-over peatbog (Le Russey, Jura Mountains, France). Organic Geochemistry 37, 1736-1751.

Dedysh, S.N., Pankratov, T.A., Belova, S.E., Kulichevskaya, I.S., Liesack, W., 2006. Phylogenetic analysis and in situ identification of bacteria community composition in an acidic sphagnum peat bog. Applied and Environmental Microbiology 72, 2110-2117.

Delarue F., Laggoun-Défarge F., Disnar J.R., Lottier N., Gogo S. Organic matter sources and decay assessment in two moisture conditions of a Sphagnum-dominated peatland. Biogeochemistry, submitted.

Disnar, J.-R., Stefanova, M., Bourdon, S., Laggoun-Défarge, F., 2005. Sequential fatty acid analysis of a peat core covering the last two millenia (Tritrivakely lake, Madagascar): Diagenesis appraisal and consequences for paleoenvironmental reconstruction. Organic Geochemistry 36, 1391-1404.

Garcette-Lepecq, A., Largeau, C., Bouloubassi, I., Derenne, S., Saliot, A., Lorre, A., Point, V., 2004. Lipids and their modes of occurrence in two surface sediments from the Danube delta and northwestern Black Sea: implications for sources and early diagenetic alteration I. Carboxylic acids. Organic Geochemistry 35, 959-980.

Gorham, E., 1991. Northern peatlands: role in carbon cycle and probable responses to climate warming. Ecological Applications 1:182-195. 
Harriss, R., Bartlett, K., Frolking, S., Crill, P., 1993. Methane emissions from northern highlatitude wetlands. In: Oremland, R.S. (Ed.), Biogeochemistry of Global Change. Radiatively Active Trace Gases. Chapman \& Hall, New York, pp. 449-486.

Harvey, H.R., Fallon, R.D., Patton, J.S., 1986. The effect of organic matter and oxygen on the degradation of bacterial membrane lipids in marine sediments. Geochimica et Cosmochimica Acta 50, 795-804.

Hopmans, E.C., Schouten, S., Pancost, R.D., van der Meer, M.T.J., Sinninghe Damsté, J.S., 2000. Analysis of intact GDGT lipids in archaeal cell material and sediments by high performance liquid chromatography/atmospheric pressure chemical ionization mass spectrometry. Rapid Communications in Mass Spectrometry 14, 585-589.

Hopmans, E.C., Weijers, J.W.H., Schefuß, E., Herfort, L., Sinninghe Damsté, J.S., Schouten, S., 2004. A novel proxy for terrestrial organic matter in sediments based on branched and isoprenoid tetraether lipids. Earth and Planetary Science Letters 224, 107-116.

Huguet, A., Fosse, C., Metzger, P., Fritsch, E., Derenne, S., 2010. Distribution of extractable glycerol dialkyl glycerol tetraethers in podzols. Organic Geochemistry 41, 291-301.

Huguet, A., Fosse, C., Metzger, P., Fritsch, E., Derenne, S. Distribution of non-extractable glycerol dialkyl glycerol tetraethers in temperate and tropical podzols: implications for the reconstruction of mean air temperature. Organic Geochemistry, submitted.

Huguet, C., de Lange, G.J., Gustafsson, O., Middelburg, J.J., Sinninghe Damsté, J.S., Schouten, S., 2008. Selective preservation of soil organic matter in oxidized marine sediments (Madeira Abyssal Plain). Geochimica et Cosmochimica Acta 72, 6061-6068.

Karner, M.B., DeLong, E.F., Karl, D.M., 2001. Archaeal dominance in the mesopelagic zone of the Pacific Ocean. Nature 409, 507-510.

Kawamura, K., Ishiwatari, R., 1984. Tightly bound aliphatic acids in Lake Biwa sediments: their origin and stability. Organic Geochemistry 7, 121-126.

Keough, B.P., Schmidt, T.M., Hicks, R.E., 2003. Archaeal nucleic acids in picoplankton from great lakes on three continents. Microbial Ecology 46, 238-248.

Kim, J.-H., Ludwig, W., Schouten, S., Kerhervé, P., Herfort, L., Bonnin, J., Sinninghe Damsté, J.S., 2007. Impact of flood events on the transport of terrestrial organic matter to the ocean: A study of the Têt River (SW France) using the BIT index. Organic Geochemistry 38, 1593-1606.

Kim, J.-H., Schouten, S., Hopmans, E.C., Donner, B., Sinninghe Damsté, J.S., 2008. Global sediment core-top calibration of the $\mathrm{TEX}_{86}$ paleothermometer in the ocean. Geochimica et Cosmochimica Acta 72, 1154-1173.

Kivinen, E., Pakarinen. P., 1981. Geographical distribution of peat resource and major peatland complex types in the world. Annales Academiae Scientiraum Fennicae Series A3 $132,1-28$. 
Koga, Y., Nishihara, M., Morii, H., Akagawa-Matsushita, M., 1993. Ether polar lipids of methanogenic bacteria: structures, comparative aspects and biosyntheses. Microbiology Reviews 57, 164-182.

Koster, R.D., Dirmeyer, P.A., Guo, Z., Bonan, G., Chan , E., Cox, P., Gordon, C.T., Kanae, S., Kowalczyk, Lawrence, D., Liu, P., Lu, C.-H., Malyshev, S., McAvaney, B., Mitchell, K., Mocko, D., Oki, T., Oleson, K., Pitman, A., Sud, Y.C., Taylor, C.M., Verseghy, D., Vasic, R., Xue, Y., Yamada, T., 2004. Regions of strong coupling between soil moisture and precipitation. Science 305, 1138-1140.

Kotsyurbenko, O.R., Chin, K.J., Glagolev, M.V., Stubner, S., Simankova, M.V., Nozhevnikova, A.N., Conrad, R., 2004. Acetoclastic and hydrogenotrophic methane production and methanogenic populations in an acidic West-Siberian peat bog. Environmental Microbiology 6, 1159-1173.

Kuypers, M.M., Blokker, P., Erbacher, J., Kinkel, H., Pancost, R.D., Schouten, S., Sinninghe Damsté, J.S., 2001. Massive expansion of marine archaea during a mid-cretaceous oceanic anoxic event. Science 293, 92-94.

Laggoun-Défarge, F., Gilbert, D., Buttler, A., Epron, D., Francez, A.-J., Grasset, L., Guimbaud, C., Mitchell, A.D., Roy, J.-C, 2008. Effect of experimental warming on carbon sink function of a temperate pristine mire: the PEATWARM project. In: C. Farrell, C., J. Feehan, J. (Eds.), After Wise Use - The Future of Peatlands, Proceedings of the 13th International Peat Congress, Ireland, Tullamore, 8-13 June 2008. IPS, Finland, pp. 599602.

Laiho, R., 2006. Decomposition in peatlands: reconciling seemingly contrasting results on the impacts of lowered water table level. Soil Biology and Biochemistry 38, 2011-2024.

Leininger, S., Urich, T., Schloter, M., Schwark, L., Qi, J., Nicol, G.W., Prosser, J.I., Schuster, S.C., Schleper, C., 2006. Archaea predominate among ammonia-oxidizing prokaryotes in soils. Nature 442, 806-809.

Lipp, J.S., Morono, Y., Inagaki, F., Hinrichs, K.-U., 2008. Significant contribution of Archaea to extant biomass in marine subsurface sediments. Nature 454, 991-994.

Macnaughton, S.J., Jenkins, T.L., Wimpee, M.H., Cormiér, M., White, D.C., 1997. Rapid extraction of lipid biomarkers from pure culture and environmental samples using pressurized accelerated hot solvent extraction. Journal of Microbiological Methods 31, 1927.

Matthews, E., Fung, I., 1987. Methane emission from natural wetlands: Global distribution, area, and environmental characteristics of sources. Global Biogeochemical Cycles 1, 6186.

Naccarato, W.F., Gilbertson, J.R., Gelman, R.A., 1974. Effects of different culture media and oxygen upon lipids of Escherichia coli K-12. Lipids 9, 322-327. 
Nishihara, M., Koga, Y., 1987. Extraction and composition of polar lipids from the archaebacterium Methanobacterium thermoautotrophicum: effective extraction of tetraether lipids by an acidified solvent. Journal of Biochemistry 101, 997-1005.

Otto, A., Simpson, M.J., 2006. Sources and composition of hydrolysable aliphatic lipids and phenols in soils from Western Canada. Organic Geochemistry 37, 385-407.

Pancost, R.D., van Geel, B., Baas, M., Sinninghe Damsté, J.S., 2000. $\delta^{13} \mathrm{C}$ values and radiocarbon dates of microbial biomarkers as tracers for carbon recycling in peat deposits. Geology 28, 663-666.

Peters, K. E., Walters, C. C., Moldowan, J. M., 2005. The Biomarker Guide: Biomarkers and Isotopes in Petroleum Exploration and Earth History, 2nd ed, vol. 2. Cambridge University Press, New York, pp. 645-708.

Peterse, F., Schouten, S., van der Meer, J., van deer Meer, M.T.J., Sinninghe Damsté, J.S., 2009a. Distribution of branched tetraether lipids in geothermally heated soils: implications for the MBT/CBT temperature proxy. Organic Geochemistry 40, 201-205.

Peterse, F., Kim, J.-H., Schouten, S., Klitgaard, D. K., Koç, N., Sinninghe Damsté, J.S., $2009 \mathrm{~b}$. Constraints on the application of the MBT/CBT palaeothermometer in high latitude environments (Svalbard, Norway). Organic Geochemistry 40, 692-699.

Peterse, F., Schouten, F., Fierer, N., Jackson, R.B., Nicol, G.W., Weijers, J.W.H., van Groeningen, K.J., Wiesenberg, G.L.B., Jia, G., Sinninghe Damsté, J.S., 2009c. Environmental controls on the bacterial tetraether membrane lipid distribution in soils: implications for the MBT/CBT temperature proxy. Abstract. $24^{\text {th }}$ International Meeting on Organic Geochemistry, Bremen, Germany, p. 72.

Pitcher, A., Hopmans, E.C., Schouten, S., Sinninghe Damsté, J.S., 2009. Separation of core and intact polar archaeal tetraether lipids using silica columns: Insights into living and fossil biomass contributions. Organic Geochemistry 40, 12-19.

Powers, L.A., Werne, J.P., Johnson, T.C., Hopmans, E.C., Sinninghe Damsté, J.S., Schouten, S., 2004. Crenarchaeotal membrane lipids in lake sediments: a new paleotemperature proxy for continental paleoclimate reconstruction? Geology 32, 613-616.

Rossel, P. E., Lipp, J. S., Fredricks, H. F., Arnds, J., Boetius, A., Elvert, M., Hinrichs, K.-U. , 2008. Intact polar lipids of anaerobic methanotrophic archaea and associated bacteria. Organic Geochemistry 39, 992-999.

Rueda, G., Rosell-Melé, A., Escala, M., Gyllencreutz, R., Backman, J., 2009. Comparison of instrumental and GDGT based estimates of sea surface and air temperatures from the Skagerrak. Organic Geochemistry 40, 287-291.

Safe, S., Duncan, J., 1974. Effect of oxygen levels on the fatty acids and lipids of Mucor rouxii. Lipids 9, 285-289.

Schouten, S., Hopmans, E.C., Pancost, R.D., Sinninghe Damsté, J.S., 2000. Widespread occurrence of structurally diverse tetraether membrane lipids: evidence for the ubiquitous 
presence of low-temperature relatives of hyperthermophiles. Proceedings of the National Academy of Sciences USA 97, 14421-14426.

Schouten, S., van der Meer, M.T.J., Hopmans, E.C., Rijpstra, W.I.C., Reysenbach, A.-L., Ward, D.M., Sinninghe Damsté, J.S., 2007. Archaeal and bacterial glycerol dialkyl glycerol tetraether lipids in hot springs of Yellowstone national park. Applied and Environmental Microbiology 73, 6181-6191.

Schouten, S., Eldrett, J., Greenwood, D.R., Harding, I., Baas, M., Sinninghe Damsté, J.S., 2008. Onset of long-term cooling of Greenland near the Eocene-Oligocene boundary as revealed by branched tetraether lipids. Geology 36, 147-150.

Sinninghe Damsté, J.S., Hopmans, E.C., Pancost, R.D., Schouten, S., Geenevasen, J.A.J., 2000. Newly discovered non-isoprenoid glycerol dialkyl glycerol tetraether lipids in sediments. Chemical Communications 1683-1684.

Sinninghe Damsté, J.S., Schouten, S., Hopmans, E.C., van Duin, A.C.T., Geenevasen, J.A.J., 2002. Crenarchaeol: the characteristic core glycerol dibiphytanyl glycerol tetraether membrane lipid of cosmopolitan pelagic crenarchaeota. Journal of Lipid Research 43, 1641-1651.

Sinninghe Damsté, J.S., Ossebaar, J., Schouten, S., Verschuren, D., 2008. Altitudinal shifts in the branched tetraether lipid distribution in soil from Mt. Kilimanjaro (Tanzania): Implications for the MBT/CBT continental palaeothermometer. Organic Geochemistry 39, 1072-1076.

Sturt, H.F., Summons, R.E., Smith, K., Elvert, M., Hinrichs, K.-U., 2004. Intact polar membrane lipids in prokaryotes and sediments deciphered by high-performance liquid chromatography/electrospray ionization multistage mass spectrometry - new biomarkers for biogeochemistry and microbial ecology. Rapid Communications in Mass Spectrometry $18,617-628$.

Svenson, S., Thompson, D.H., 1998. Facile and efficient synthesis of bolaamphilic tetraether phosphocholines. The Journal of Organic Chemistry 21, 7180-7182.

Teske, A., Sørensen, K.B., 2008. Uncultured archaea in deep marine subsurface sediments: have we caught them all? The ISME Journal 2, 3-18.

Tierney, J.E., Russell, J.M., 2009. Distributions of branched GDGTs in a tropical lake system: implications for lacustrine application of the MBT/CBT paleoproxy. Organic Geochemistry 40, 1032-1036.

Utsumi, M., Belova, S.E., King, G.M., Uchiyama, H., 2003. Phylogenetic comparison of methanogen diversity in different wetland soils. Journal of General and Applied Microbiology 49, 75-83.

Weijers, J.W.H., Schouten, S., van der Linden, M., van Geel, B., Sinninghe Damsté, J.S., 2004. Water table related variations in the abundance of intact archaeal membrane lipids in a Swedish peat bog. FEMS Microbiology Letters 239, 51-56. 
Weijers, J.W.H., Schouten, S., Hopmans, E.C., Geenevasen, J.A.J., David, O.R.P., Coleman, J.M., Pancost, R.D., Sinninghe Damsté, J.S., 2006a. Membrane lipids of mesophillic anaerobic bacteria thriving in peats have typical archaeal traits. Environmental Microbiology 8, 648-657.

Weijers, J.W.H., Schouten, S., Spaargaren, O.C., Sinninghe Damsté, J.S., 2006b. Occurrence and distribution of tetraether membrane lipids in soils: implications for the use of the BIT index and the TEX ${ }_{86}$ SST proxy. Organic Geochemistry 37, 1680-1693.

Weijers, J.W.H., Schouten, S., van den Donker, J.C., Hopmans, E.C., Sinninghe Damsté, J.S., 2007a. Environmental controls on bacterial tetraether membrane lipid distribution in soils, Geochimica et Cosmochimica Acta 71, 703-713.

Weijers, J.W.H., Schefuss, E., Schouten, S., Sinninghe Damsté, J.S., 2007b. Coupled thermal and hydrological evolution of tropical Africa over the last deglaciation. Science 315, 1701.

Weijers, J.W.H., Panoto, E., van Bleijswijk, J., Schouten, S., Rijpstra, W.I.C., Balk, M., Stams, A.J.M., Sinninghe Damsté, J.S., 2009. Constraints on the biological source(s) of the orphan branched tetraether membrane lipids. Geomicrobiology Journal 26, 402-414.

White, D.C., Davis, W.M., Nickels, J.S., King, J.D., Bobbie, R.J., 1979. Determination of the sedimentary microbial biomass by extractable lipid phosphate. Oecologia 40, 51-62.

Woese, C.R., Kandler, O., Wheels, M.L., 1990. Towards a natural system of organisms: proposal for the domains Archaea, Bacteria and Eucarya. Proceedings of the National Academy of Sciences USA 87, 4576-4579.

Wright, A.L., Reddy, K.R., 2001. Heterotrophic microbial activity in northern Everglades wetland soils. Soil Science Society of America Journal 65, 1856-1864.

Yavitt, J.B., Lang, G.E., Wieder, R.K., 1987. Control of carbon mineralization to $\mathrm{CH}_{4}$ and $\mathrm{CO}_{2}$ in anaerobic, Sphagnum-derived peat from Big Run Bog, West Virginia. Biogeochemistry 4, 141-157. 


\section{Appendix}

Structures of glycerol dialkyl glycerol tetraether (GDGT) membrane lipids of archaeal and bacterial origin in peat samples and of internal standard (IS) used for quantification.

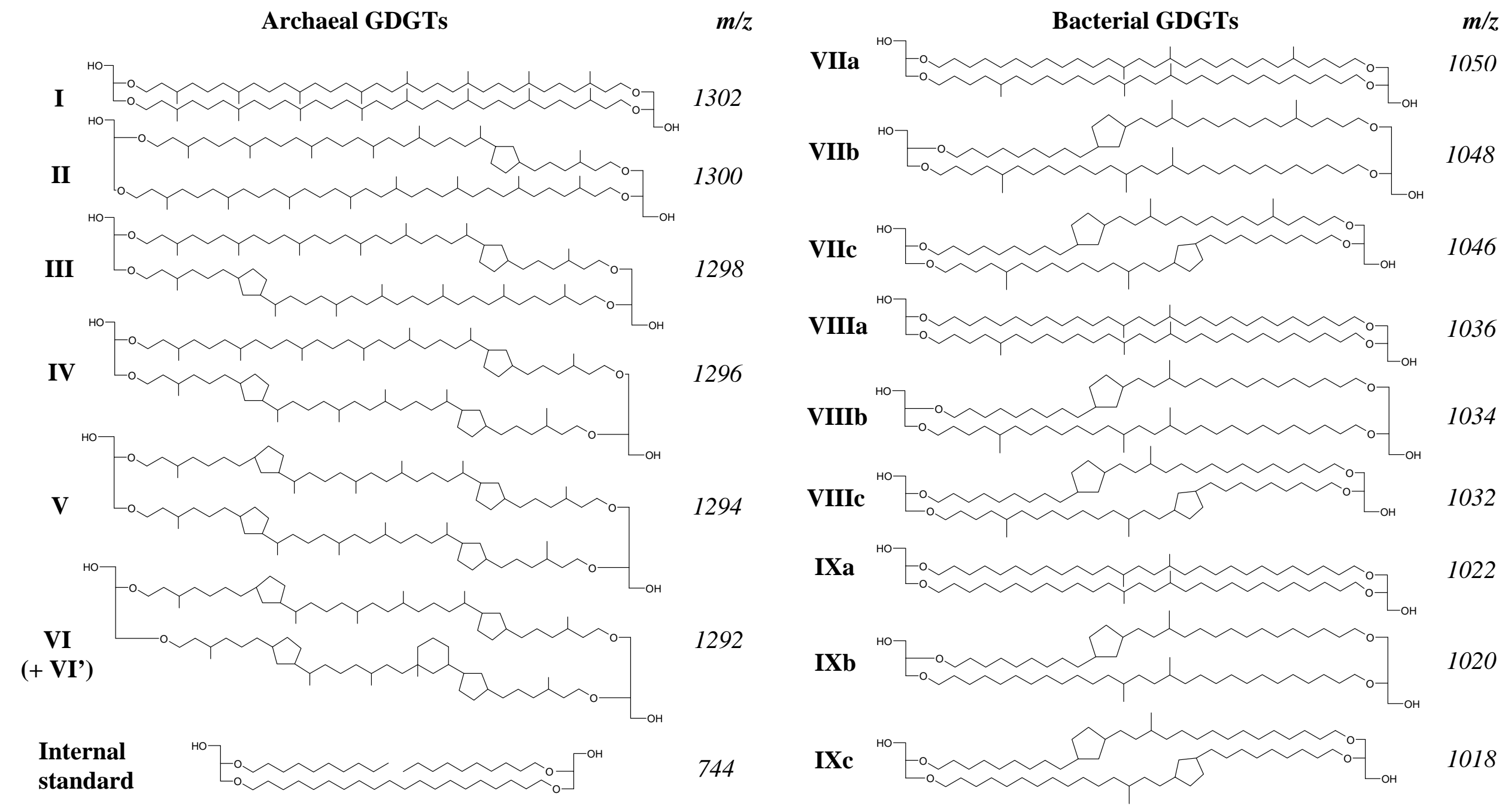




\section{Captions to figures}

Fig. 1. Flow chart of treatment for isolation of extractable "free", total extractable and nonextractable GDGTs.

Fig. 2. Amount ( $\mu \mathrm{g} \mathrm{g}^{-1} \mathrm{TOC}$, in bold) and relative abundance of (a) bacterial and (b) archaeal GDGTs in extractable "free" and extractable "bound" lipid fractions obtained via ASE and Bligh and Dyer extractions of peat samples (Frasne, France). TOC, total organic carbon. Please note that the HPLC/MS analysis error is ca.10\%.

Fig. 3. Amount ( $\mu \mathrm{g} \mathrm{g}^{-1} \mathrm{TOC}$, in bold) and relative abundance of bacterial and archaeal GDGTs in total extractable and non-extractable lipid fractions obtained via chemical treatment of ASE-extracted peat samples (Frasne, France).

Fig. 4. Values of (a) the methylation index (MBT) and (b) the cyclisation ratio (CBT) of bacterial tetraethers in the extractable "free", total extractable and non-extractable lipid fractions. The extractable "free" and total extractable lipid fractions were obtained after extraction of peat samples using either ASE or Bligh and Dyer techniques. Non-extractable GDGTs were recovered from ASE-extracted peat samples. Average duplicate errors for MBT and CBT are 0.005 and 0.02 respectively.

\section{Captions to tables}

\section{Table 1}

Amount (ng g ${ }^{-1}$ dry wt peat) and relative abundance (\%) of different archaeal and bacterial GDGTs in extractable "free", total extractable and non-extractable lipid fractions obtained after ASE and Bligh and Dyer extractions of peat samples (n.d., not detected).

\section{Table 2}

General properties ( $\mathrm{pH}$, TOC content) of peat samples, proxy values (MBT and CBT) and estimated $\mathrm{pH}$ and mean annual air temperature (MAAT) values from MBT and CBT indices (n.d., not determined).

\section{Table 3}

Values of air and soil temperatures measured over the year 2009 at the dry and wet sites of Frasne peat bog. 


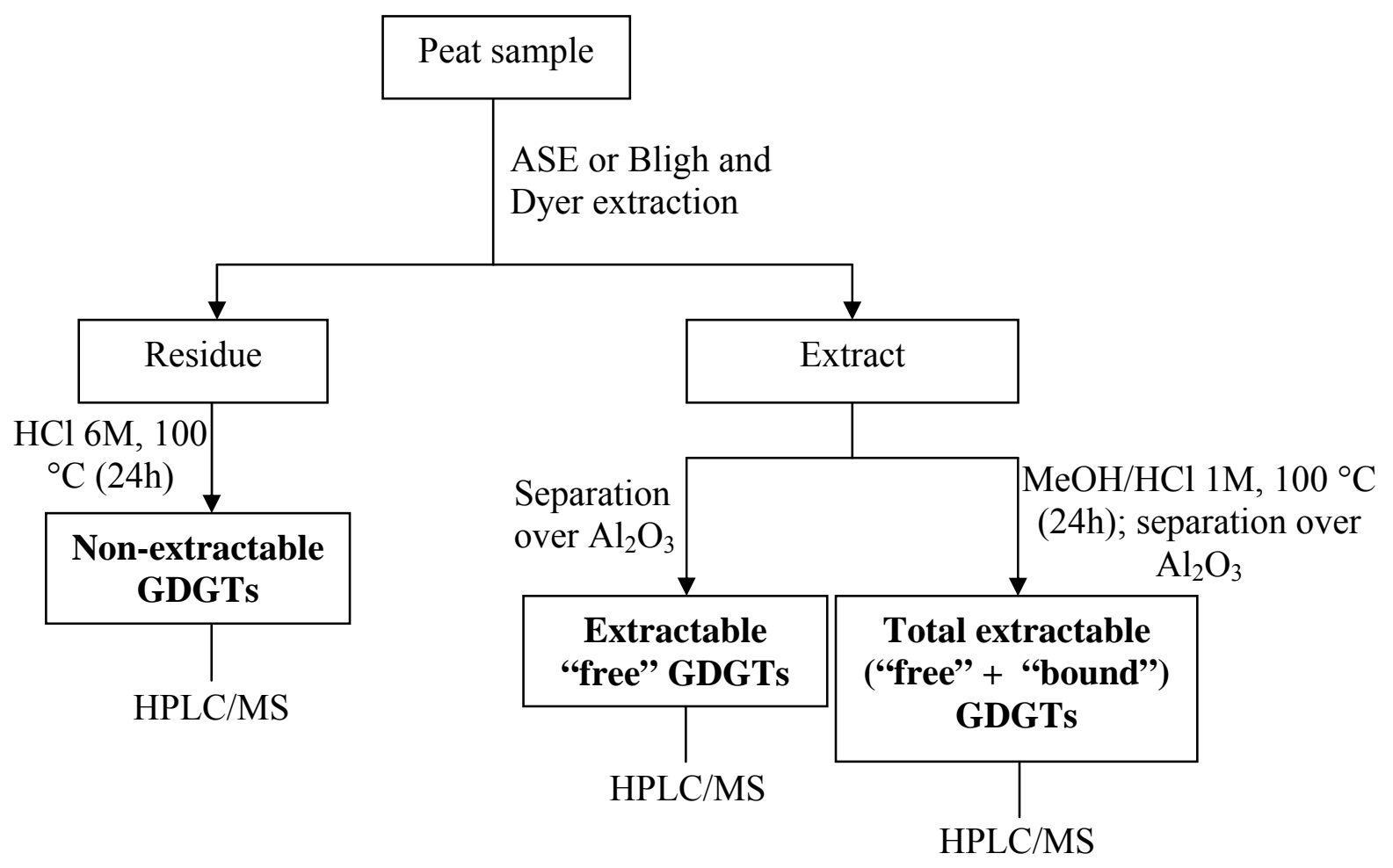

Fig. 1. 
(a)

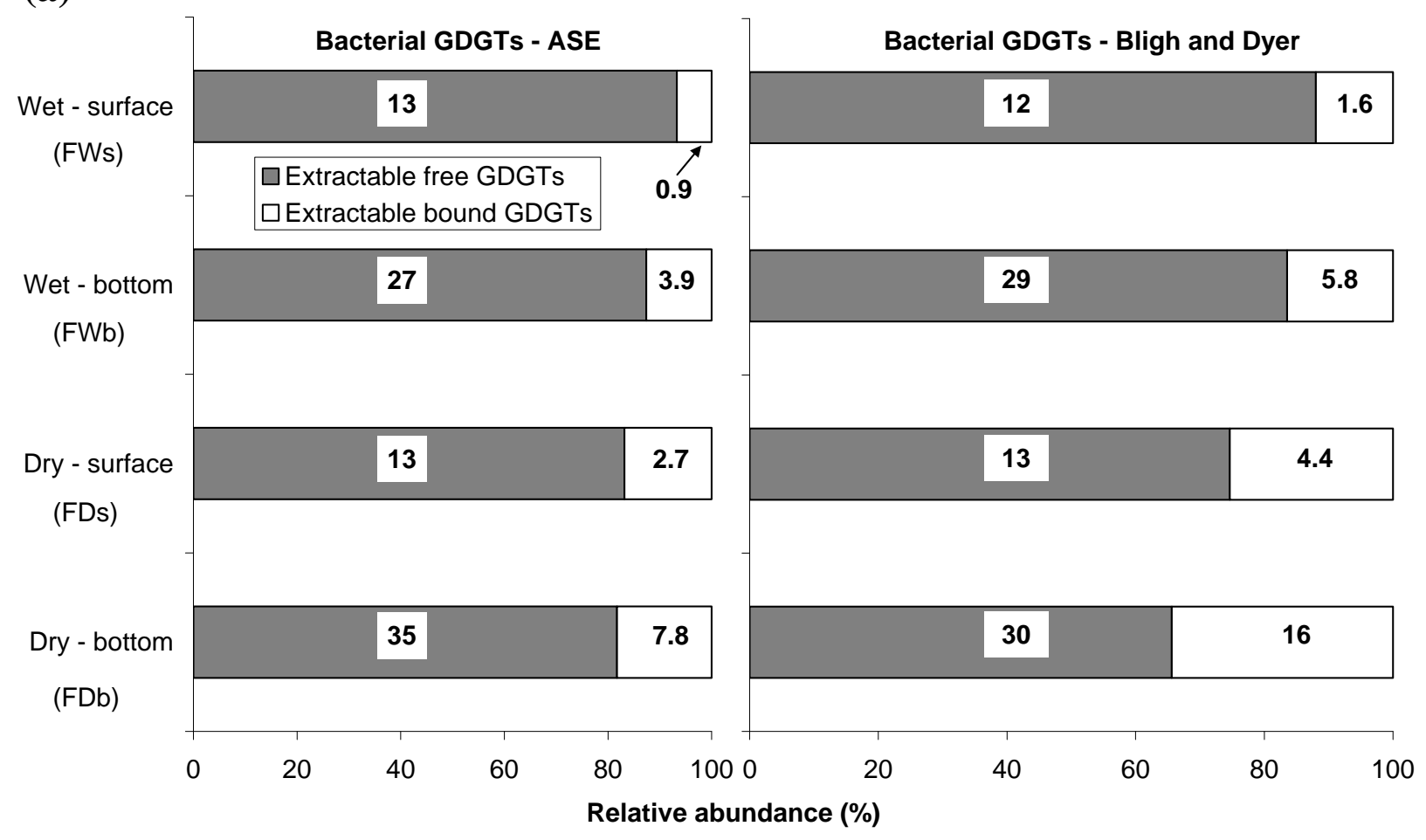

(b)

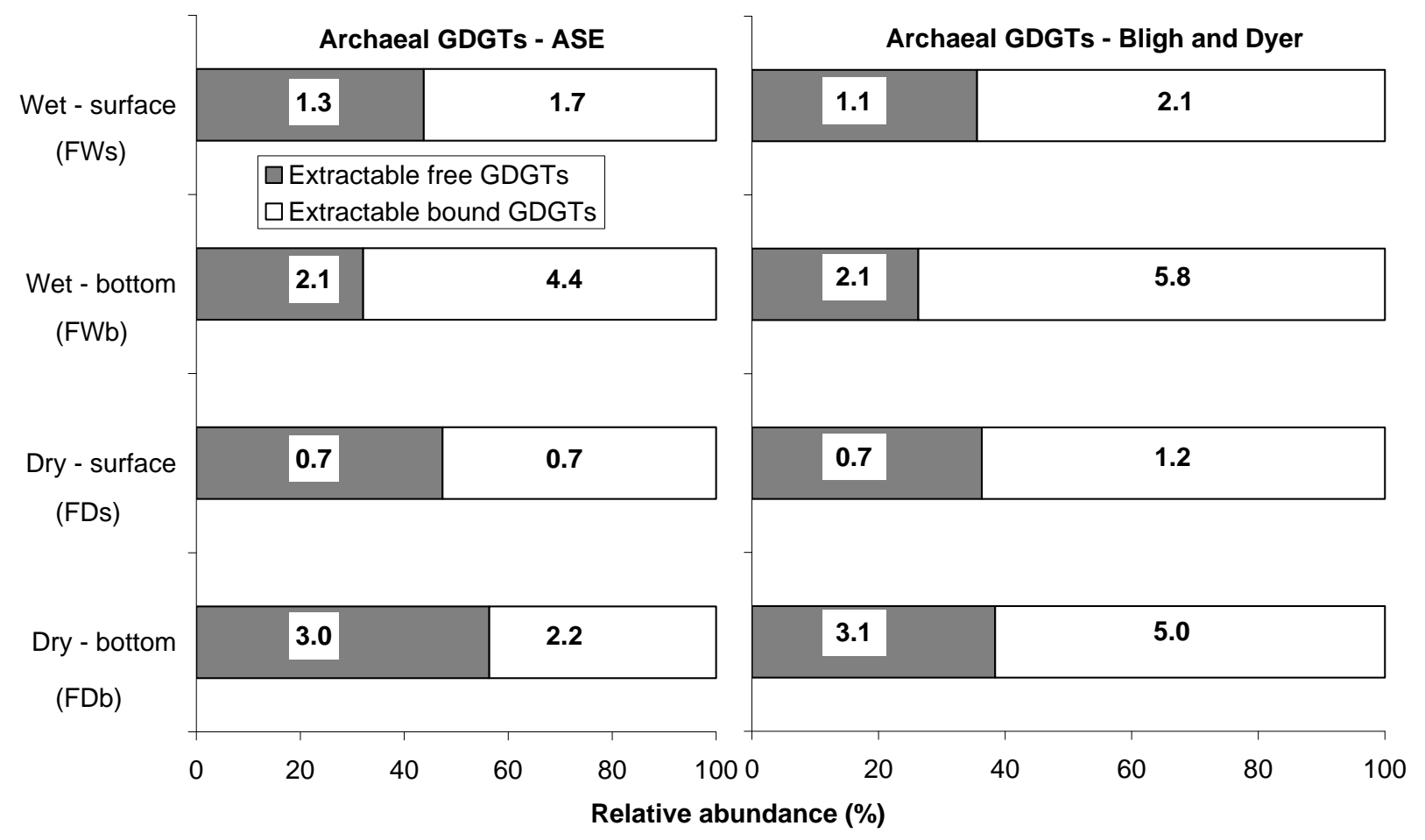

Fig. 2. 


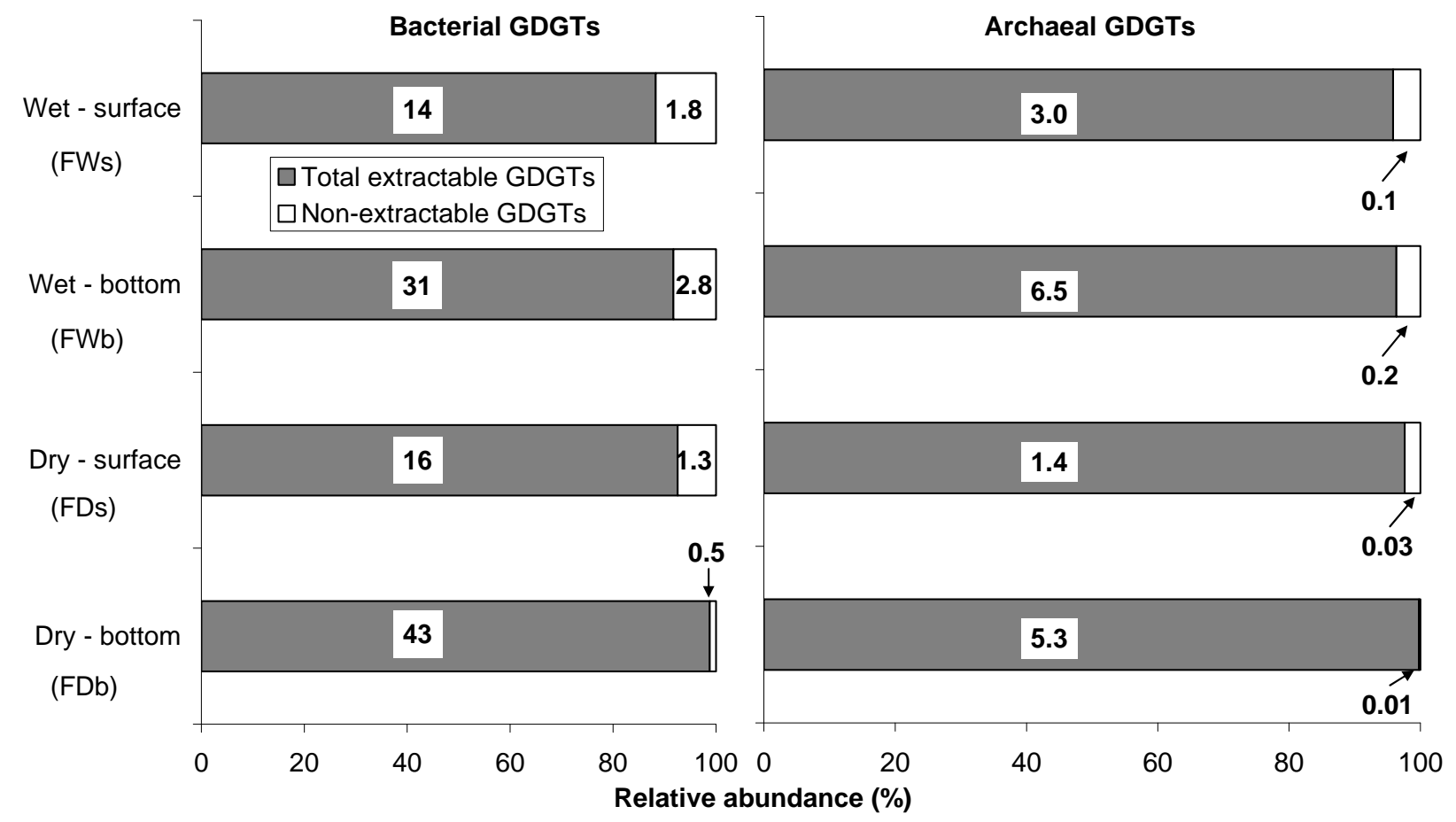

Fig. 3. 
(a)

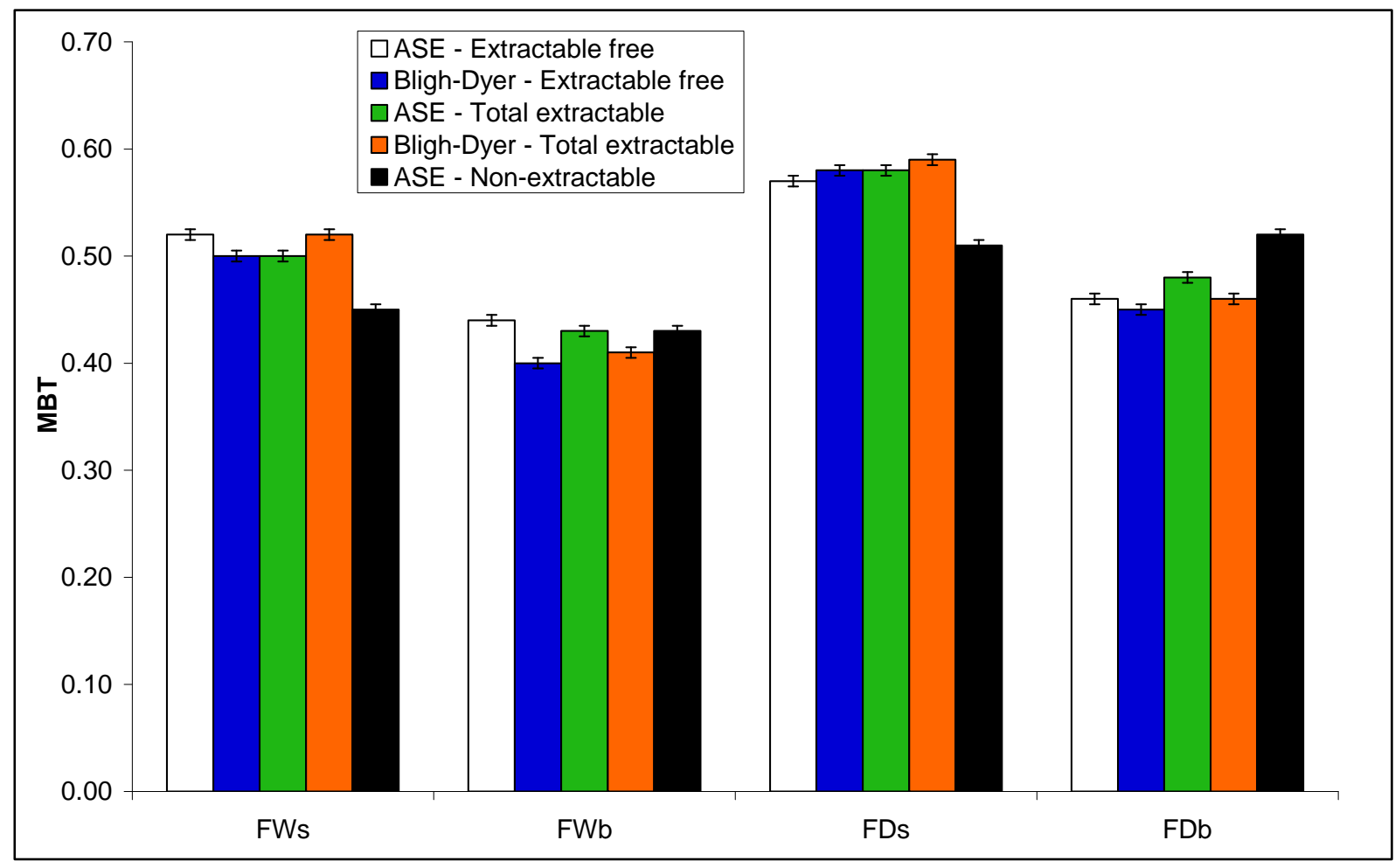

(b)

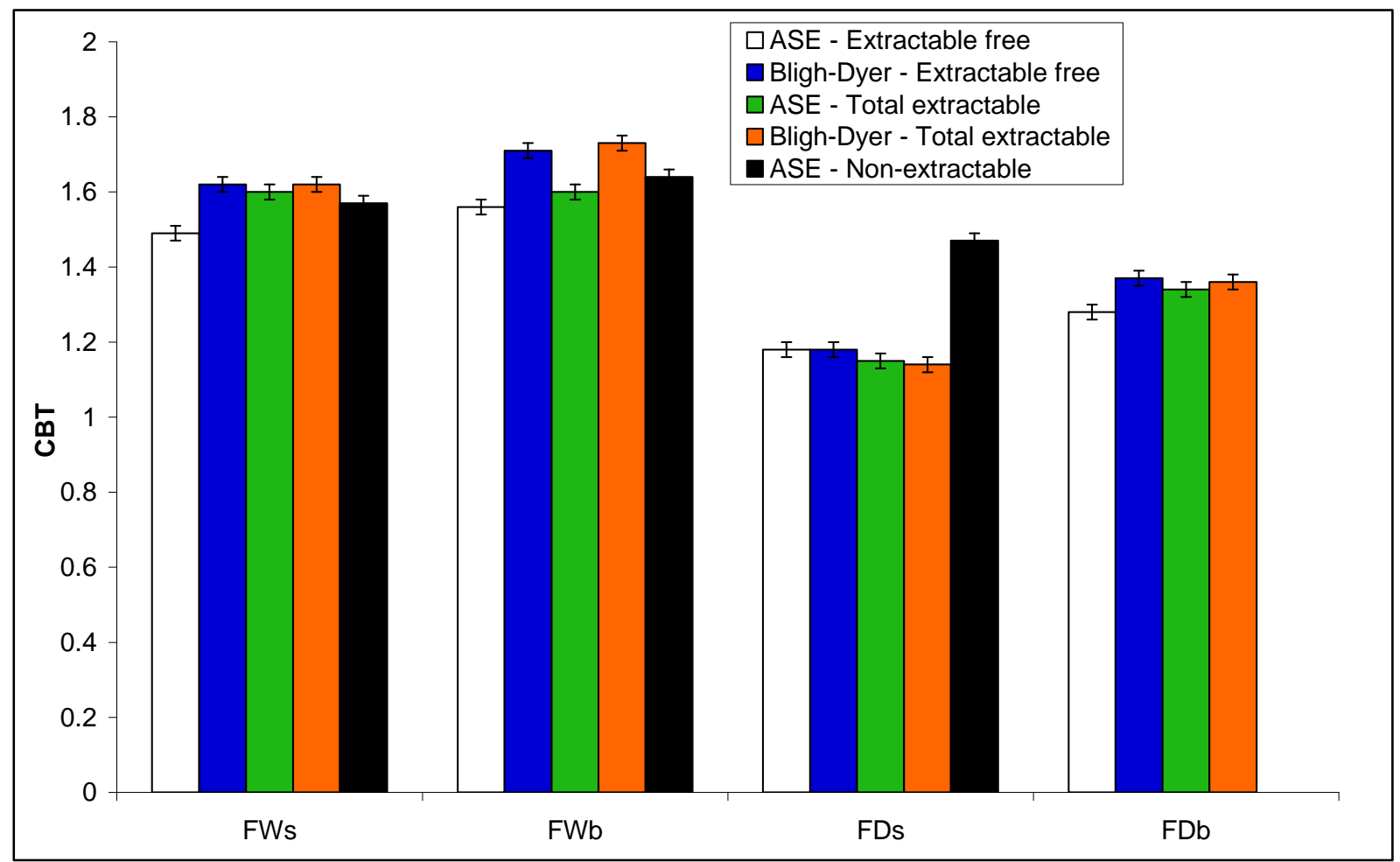

Fig. 4. 


\begin{tabular}{|c|c|c|c|c|c|c|c|c|c|c|c|c|c|c|c|c|c|c|}
\hline \multirow[b]{2}{*}{ Sample } & \multirow[b]{2}{*}{ Fraction } & \multirow[b]{2}{*}{ Method } & \multicolumn{6}{|c|}{ Archaea } & \multicolumn{9}{|c|}{ Bacteria } & \multirow[b]{2}{*}{ Bact./Arch. ${ }^{a}$} \\
\hline & & & $\mathrm{I}$ & II & III & IV & $\mathrm{V}$ & Total & VIla & VIllb & VIIIIa & VIIIIb & VIIIC & $\mathrm{IXa}$ & $\mathrm{IXb}$ & $\mathrm{IXc}$ & Total & \\
\hline Wet site - & & ASE & $438(81.2)$ & $40(7.5)$ & $61(11.3)$ & n.d. & n.d. & $540(100.0)$ & $421(8.1)$ & $7(0.1)$ & $2030(38.9)$ & $35(0.7)$ & $18(0.4)$ & $2532(48.5)$ & $112(2.1)$ & $65(1.2)$ & $5220(100.0)$ & 9.7 \\
\hline Wet site - & Extractable tree & Bligh-Dyer & $407(84.7)$ & $25(5.1)$ & $49(10.2)$ & n.d. & n.d. & $480(100.0)$ & $374(7.7)$ & n.d. & $2033(41.6)$ & $30(0.6)$ & $18(0.4)$ & $2347(48.0)$ & $75(1.5)$ & $9(0.2)$ & $4884(100.0)$ & 10.2 \\
\hline surface & Total extractable & $\begin{array}{c}\text { ASE } \\
\text { Bligh-Dyer }\end{array}$ & $\begin{array}{c}971(78.7) \\
1152(85.3)\end{array}$ & $\begin{array}{l}69(5.6) \\
82(6.1)\end{array}$ & $\begin{array}{c}103(8.4) \\
86(6.4)\end{array}$ & $\begin{array}{l}64(5.2) \\
31(2.3)\end{array}$ & $\begin{array}{l}26 \text { (2.1) } \\
\text { n.d. }\end{array}$ & $\begin{array}{l}1234(100.0) \\
1351(100.0)\end{array}$ & $\begin{array}{l}447(8.0) \\
378(6.8)\end{array}$ & $\begin{array}{l}\text { n.d. } \\
\text { n.d. }\end{array}$ & $\begin{array}{l}2286(40.8) \\
2225(40.0)\end{array}$ & $\begin{array}{l}42(0.8) \\
20(0.4)\end{array}$ & $\begin{array}{l}28(0.5) \\
18(0.3)\end{array}$ & $\begin{array}{l}2692(48.1) \\
2784(50.2)\end{array}$ & $\begin{array}{c}82(1.5) \\
100(1.8)\end{array}$ & $\begin{array}{l}19(0.3) \\
24(0.4)\end{array}$ & $\begin{array}{l}5595(100.0) \\
5550(100.0)\end{array}$ & $\begin{array}{l}4.5 \\
4.1\end{array}$ \\
\hline (FWs) & Non-extractable & ASE & $47(88.4)$ & $2(3.5)$ & n.d. & $4(8.1)$ & n.d. & $54(100.0)$ & $81(11.0)$ & n.d. & $313(42.3)$ & $11(1.4)$ & n.d. & $326(44.0)$ & $6(0.9)$ & $3(0.4)$ & $741(100.0)$ & 13.8 \\
\hline Wet site - & Extractable free & $\begin{array}{c}\text { ASE } \\
\text { Bligh-Dyer }\end{array}$ & $\begin{array}{l}917(100.0) \\
891(97.8)\end{array}$ & $\begin{array}{c}\text { n.d. } \\
20(2.2)\end{array}$ & $\begin{array}{l}\text { n.d. } \\
\text { n.d. }\end{array}$ & $\begin{array}{l}\text { n.d. } \\
\text { n.d. }\end{array}$ & $\begin{array}{l}\text { n.d. } \\
\text { n.d. }\end{array}$ & $\begin{array}{l}917(100.0) \\
910(100.0)\end{array}$ & $\begin{array}{l}1646(13.8) \\
1744(13.4)\end{array}$ & $\begin{array}{l}5(0.1) \\
\text { n.d. }\end{array}$ & $\begin{array}{l}5036(421) \\
5900(45.5)\end{array}$ & $\begin{array}{l}26(0.2) \\
42(0.3)\end{array}$ & $\begin{array}{l}26(0.2) \\
24(0.2)\end{array}$ & $\begin{array}{l}4911 \text { (41.1) } \\
5053(39.0)\end{array}$ & $\begin{array}{l}251(2.1) \\
173(1.3)\end{array}$ & $\begin{array}{l}41(0.3) \\
30(0.2)\end{array}$ & $\begin{array}{l}11943(100.0) \\
12966(100.0)\end{array}$ & $\begin{array}{l}13.0 \\
14.2\end{array}$ \\
\hline bottom & Total extractable & $\begin{array}{c}\text { ASE } \\
\text { Bligh-Dyer }\end{array}$ & $\begin{array}{l}2661 \text { (93.1) } \\
3263(94.2)\end{array}$ & $\begin{array}{c}85(3.0) \\
129(3.7)\end{array}$ & $\begin{array}{l}74(2.6) \\
37(1.1)\end{array}$ & $\begin{array}{l}39(1.3) \\
34(1.0)\end{array}$ & $\begin{array}{l}\text { n.d. } \\
\text { n.d. }\end{array}$ & $\begin{array}{l}2859(100.0) \\
3464(100.0)\end{array}$ & $\begin{array}{l}1973(14.4) \\
2163(13.9)\end{array}$ & $\begin{array}{c}2(0.1) \\
\text { n.d. }\end{array}$ & $\begin{array}{l}5651(41.2) \\
6926(44.6)\end{array}$ & $\begin{array}{l}70(0.5) \\
48(0.3)\end{array}$ & $\begin{array}{l}51(0.4) \\
52(0.3)\end{array}$ & $\begin{array}{l}5619(41.1) \\
6041(38.9)\end{array}$ & $\begin{array}{l}215(1.6) \\
191(1.2)\end{array}$ & $\begin{array}{l}84(0.6) \\
97(0.6)\end{array}$ & $\begin{array}{l}13665(100.0) \\
15518(100.0)\end{array}$ & $\begin{array}{l}4.8 \\
4.5\end{array}$ \\
\hline (FWb) & Non-extractable & ASE & $86(79.6)$ & $8(7.7)$ & $8(6.9)$ & $6(5.7)$ & n.d. & $108(100.0)$ & $136(11.0)$ & $1(0.1)$ & $553(44.8)$ & $10(0.8)$ & $5(0.4)$ & $507(41.1)$ & $14(1.2)$ & $7(0.6)$ & $1232(100.0)$ & 11.4 \\
\hline Dry site - & Extractable free & $\begin{array}{c}\text { ASE } \\
\text { Bligh-Dyer }\end{array}$ & $\begin{array}{l}157(52.9) \\
232(72.2)\end{array}$ & $\begin{array}{c}47(16.0) \\
24(7.6)\end{array}$ & $\begin{array}{l}92(31.1) \\
65(20.2)\end{array}$ & $\begin{array}{l}\text { n.d. } \\
\text { n.d. }\end{array}$ & $\begin{array}{l}\text { n.d. } \\
\text { n.d. }\end{array}$ & $\begin{array}{l}296(100.0) \\
321(100.0)\end{array}$ & $\begin{array}{l}342(5.7) \\
333(5.7)\end{array}$ & $\begin{array}{l}\text { n.d. } \\
\text { n.d. }\end{array}$ & $\begin{array}{l}2139(36.0) \\
2107(35.8)\end{array}$ & $\begin{array}{l}26(0.4) \\
18(0.3)\end{array}$ & $\begin{array}{l}23(0.4) \\
18(0.3)\end{array}$ & $\begin{array}{l}3096(52.1) \\
3040(51.7)\end{array}$ & $\begin{array}{l}317(5.3) \\
320(5.4)\end{array}$ & $\begin{array}{c}\text { n.d. } \\
45(0.8)\end{array}$ & $\begin{array}{l}5943(100.0) \\
5880(100.0)\end{array}$ & $\begin{array}{l}20.1 \\
18.3\end{array}$ \\
\hline surface & Total extractable & $\begin{array}{c}\text { ASE } \\
\text { Bligh-Dyer }\end{array}$ & $\begin{array}{l}369(59.0) \\
636(71.9)\end{array}$ & $\begin{array}{c}120(19.1) \\
95(10.8)\end{array}$ & $\begin{array}{l}96(15.3) \\
95(10.8)\end{array}$ & $\begin{array}{l}41(6.5) \\
57(6.5)\end{array}$ & $\begin{array}{l}\text { n.d. } \\
\text { n.d. }\end{array}$ & $\begin{array}{l}626(100.0) \\
885(100.0)\end{array}$ & $\begin{array}{l}468(6.5) \\
439(5.6)\end{array}$ & $\begin{array}{l}7(0.1) \\
\text { n.d. }\end{array}$ & $\begin{array}{l}2488(34.8) \\
2703(34.3)\end{array}$ & $\begin{array}{l}30(0.4) \\
41(0.5)\end{array}$ & $\begin{array}{l}22(0.3) \\
27(0.3)\end{array}$ & $\begin{array}{l}3719 \text { (52.1) } \\
4121(52.3)\end{array}$ & $\begin{array}{l}411(5.8) \\
458(5.8)\end{array}$ & $\begin{array}{l}\text { n.d. } \\
90(1.1)\end{array}$ & $\begin{array}{l}7146(100.0) \\
7878(100.0)\end{array}$ & $\begin{array}{c}11.4 \\
8.9\end{array}$ \\
\hline (FDs) & Non-extractable & ASE & $15(100.0)$ & n.d. & n.d. & n.d. & n.d. & $15(100.0)$ & $38(6.6)$ & n.d. & $243(42.2)$ & $2(0.3)$ & n.d. & $277(48.1)$ & $16(2.7)$ & n.d. & $576(100.0)$ & 37.6 \\
\hline Dry site - & Extractable free & $\begin{array}{c}\text { ASE } \\
\text { Bligh-Dyer }\end{array}$ & $\begin{array}{l}1228(82.6) \\
1280(81.6)\end{array}$ & $\begin{array}{l}97(6.5) \\
99(6.3)\end{array}$ & $\begin{array}{c}161(10.8) \\
146(9.3)\end{array}$ & $\begin{array}{c}\text { n.d. } \\
44(2.8)\end{array}$ & $\begin{array}{l}\text { n.d. } \\
\text { n.d. }\end{array}$ & $\begin{array}{l}1486(100.0) \\
1569(100.0)\end{array}$ & $\begin{array}{l}2149(12.3) \\
1840(12.3)\end{array}$ & $\begin{array}{l}\text { n.d. } \\
\text { n.d. }\end{array}$ & $\begin{array}{l}7082(40.4) \\
6224(41.6)\end{array}$ & $\begin{array}{c}123(0.7) \\
98(0.7)\end{array}$ & $\begin{array}{l}102(0.6) \\
77(0.5)\end{array}$ & $\begin{array}{l}7346(41.9) \\
6240(41.7)\end{array}$ & $\begin{array}{l}636(3.6) \\
432(2.9)\end{array}$ & $\begin{array}{l}94(0.5) \\
54(0.4)\end{array}$ & $\begin{array}{l}17533(100.0) \\
14965(100.0)\end{array}$ & $\begin{array}{c}11.8 \\
9.5\end{array}$ \\
\hline bottom & Total extractable & $\begin{array}{c}\text { ASE } \\
\text { Bligh-Dyer }\end{array}$ & $\begin{array}{l}1992(75.5) \\
3171(76.6)\end{array}$ & $\begin{array}{l}163(6.2) \\
255(6.2)\end{array}$ & $\begin{array}{l}239(9.1) \\
348(8.5)\end{array}$ & $\begin{array}{l}161(6.1) \\
217(5.3)\end{array}$ & $\begin{array}{l}83(3.1) \\
93(2.3)\end{array}$ & $\begin{array}{l}2639(100.0) \\
4084(100.0)\end{array}$ & $\begin{array}{l}2604 \text { (12.1) } \\
2706 \text { (11.9) }\end{array}$ & $\begin{array}{l}\text { n.d. } \\
\text { n.d. }\end{array}$ & $\begin{array}{l}8175(38.1) \\
9379(41.1)\end{array}$ & $\begin{array}{l}246(1.1) \\
148(0.7)\end{array}$ & $\begin{array}{l}160(0.7) \\
116(0.5)\end{array}$ & $\begin{array}{l}9492(44.2) \\
9534(41.8)\end{array}$ & $\begin{array}{l}554(2.6) \\
681(3.0)\end{array}$ & $\begin{array}{l}222(1.0) \\
242(1.1)\end{array}$ & $\begin{array}{l}21453(100.0) \\
22805(100.0)\end{array}$ & $\begin{array}{l}8.1 \\
5.6\end{array}$ \\
\hline (FDb) & Non-extractable & ASE & $6(100.0)$ & n.d. & n.d. & n.d. & n.d. & $6(100.0)$ & $15(5.8)$ & n.d. & $110(42.3)$ & n.d. & n.d. & $135(51.9)$ & n.d. & n.d. & $261(100.0)$ & 43.5 \\
\hline
\end{tabular}

${ }^{\text {a }}$ Ratio of total bacterial GDGT concentration/total archaeal GDGT concentration. N.B., GDGTs VI, VI' and VIIc were not detected.

Table 1 


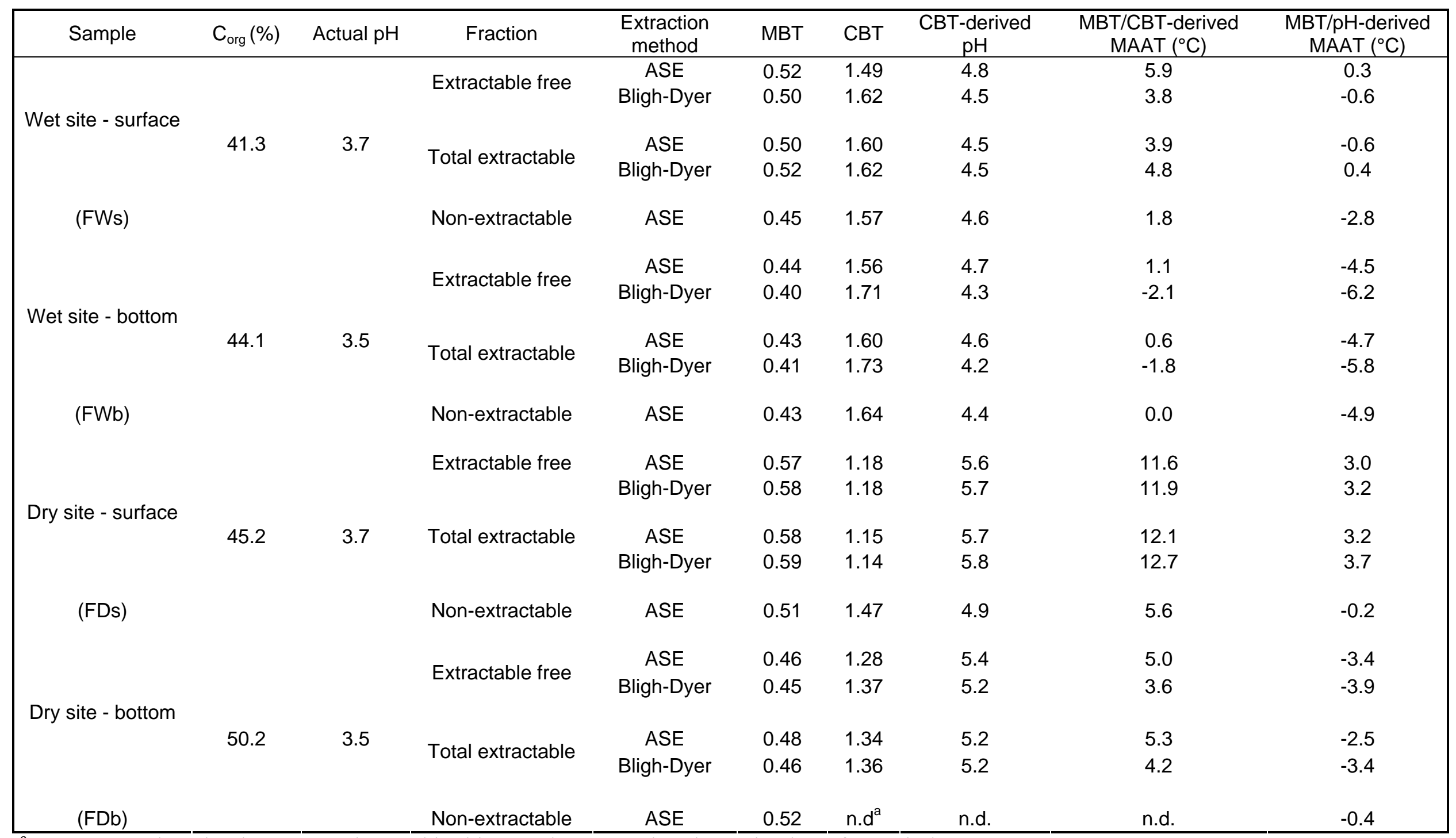

${ }^{\mathrm{a}}$ GDGTs VIIIb and IXb were not detected in this sample, preventing determination of CBT index.

Table 2 


\begin{tabular}{|c|c|c|c|c|}
\hline \multirow[b]{2}{*}{ Period (2009) } & \multirow[b]{2}{*}{ Site } & \multicolumn{3}{|c|}{ Average temperature $\left({ }^{\circ} \mathrm{C}\right)$} \\
\hline & & Air & Soil (7cm depth) & Soil (50 cm depth) \\
\hline \multirow{2}{*}{ January } & Wet & -4.4 & -0.2 & 2.1 \\
\hline & Dry & & -0.2 & 2.7 \\
\hline \multirow{2}{*}{ February } & Wet & -23 & -0.2 & 1.6 \\
\hline & Dry & & 0.0 & 2.0 \\
\hline \multirow{2}{*}{ March } & Wet & & -0.1 & 1.3 \\
\hline & Dry & 1.6 & 0.3 & 1.6 \\
\hline \multirow{2}{*}{ April } & Wet & 6.9 & 7.0 & 4.5 \\
\hline & Dry & 0.9 & 6.6 & 4.0 \\
\hline \multirow{2}{*}{ May } & Wet & & 12.6 & 8.1 \\
\hline & Dry & 12.6 & 12.0 & 8.1 \\
\hline \multirow{2}{*}{ June } & Wet & 134 & 14.4 & 11.0 \\
\hline & Dry & 13.4 & 13.8 & 11.1 \\
\hline \multirow{2}{*}{ July } & Wet & 15.4 & 16.2 & 13.0 \\
\hline & Dry & 15.4 & 15.6 & 13.1 \\
\hline \multirow{2}{*}{ August } & Wet & 15.9 & 16.1 & 13.7 \\
\hline & Dry & & 15.7 & 13.9 \\
\hline \multirow{2}{*}{ September } & Wet & & 12.3 & 12.5 \\
\hline & Dry & 11.4 & 13.7 & 12.9 \\
\hline \multirow{2}{*}{ October } & Wet & 6.3 & 7.5 & 9.9 \\
\hline & Dry & 0.3 & 6.5 & 10.2 \\
\hline \multirow{2}{*}{ November } & Wet & 47 & 5.1 & 6.9 \\
\hline & Dry & & 5.2 & 7.1 \\
\hline \multirow{2}{*}{ December } & Wet & -0.3 & 2.0 & 4.6 \\
\hline & Dry & & 2.2 & 5.0 \\
\hline \multirow{2}{*}{$\begin{array}{c}\text { Average temperature } \\
\text { January - December } 2009\end{array}$} & Wet & 68 & 7.8 & 7.5 \\
\hline & Dry & 0.8 & 7.3 & 7.7 \\
\hline \multirow{2}{*}{$\begin{array}{l}\text { Minimum temperature } \\
\text { January - December } 2009\end{array}$} & Wet & -23.2 & -0.7 & 1.2 \\
\hline & Dry & -20.2 & -0.7 & 1.4 \\
\hline \multirow{2}{*}{$\begin{array}{c}\text { Maximum temperature } \\
\text { January - December } 2009\end{array}$} & Wet & 220 & 26.1 & 14.1 \\
\hline & Dry & 32.9 & 21.2 & 14.3 \\
\hline
\end{tabular}

\section{Table 3}

